$11-1-2012$

\title{
Financiers as Monitors in Aggregate Litigation
}

\author{
Elizabeth Chamblee Burch \\ University of Georgia School of Law, eburch@uga.edu
}

P

\section{Repository Citation}

Elizabeth Chamblee Burch, Financiers as Monitors in Aggregate Litigation , 87 N.Y.U. L. Rev. 1273 (2012), Available at: https://digitalcommons.law.uga.edu/fac_artchop/856

This Article is brought to you for free and open access by the Faculty Scholarship at Digital Commons @ University of Georgia School of Law. It has been accepted for inclusion in Scholarly Works by an authorized administrator of Digital Commons @ University of Georgia School of Law. Please share how you have benefited from this access For more information, please contact tstriepe@uga.edu. 


\title{
ARTICLES
}

\section{FINANCIERS AS MONITORS IN AGGREGATE LITIGATION}

\author{
Elizabeth Chamblee Burch*
}

\begin{abstract}
This Article identifies a market-based solution for monitoring large-scale litigation proceeding outside of Rule 23's safeguards. Although class actions dominate the scholarly discussion of mass litigation, the ever increasing restrictions on certifying a class mean that plaintiffs' lawyers routinely rely on aggregate, multidistrict litigation to seek redress for group-wide harms. Despite sharing key features with its class action counterpart-such as attenuated attorney-client relationships, attorneyclient conflicts of interest, and high agency costs-no monitor exists in aggregate litigation. Informal group litigation not only lacks Rule 23's judicial protections against attorney overreaching and self-dealing, but plaintiff's themselves cannot adequately supervise their attorneys' behavior. Plaintiffs' attorneys may represent thousands of geographically dispersed clients, which fosters collective-action problems and makes individual, case-specific information hard to obtain.

An answer to this monitoring problem comes from an unlikely and potentially controversial source: alternative litigation financing. Self-dealing and high agency costs arise in aggregate litigation principally because of the contingent-fee attorney's dual roles as agent and investor. These roles can pull lawyers in divergent directions; because attorneys front massive litigation costs, they may be tempted to coerce clients into settling so that they can recoup and profit from their investment. Third-party litigation financing, which involves hedge funds, private investors, and venture capitalists investing in and profiting from large-scale litigation, can ameliorate this critical conflict of interest by allowing the financier to bear the financial risk. Shorn of financial self-interest, the lawyer is then free to act as a faithful agent. Although alternative litigation financing can be controversial, this Article seeks to marry profit-seeking capitalists and aggregate litigation in a way that benefits society as a whole and plaintiffs in particular.
\end{abstract}

INTRODUCTION ....................................... 1274

I. The Prevalence and Costs of Aggregate

Litigation ............................... 1281

A. Funding Gaps and Fee Awards .............. 1283

1. The Financial Risks of Aggregate Litigation .... 1286

* Copyright (C) 2012 by Elizabeth Chamblee Burch, Associate Professor of Law, University of Georgia School of Law. For their generous comments and criticisms on an earlier version of this paper, I am indebted to Bob Bone, Thomas Burch, Kevin Clermont, Dan Coenen, Brannon Denning, Howard Erichson, Myriam Gilles, Keith Hylton, Sam Issacharoff, Thom Main, Dan Markel, Anthony Sebok, Charlie Silver, Maya Steinitz, and Adam Zimmerman, as well as to participants in Vanderbilt Law School's 2012 New Voices in Civil Justice Scholarship Workshop and Pacific McGeorge School of Law's faculty workshop. Lennon Haas and Michael Hill provided valuable research assistance. 
2. The Added Risks of Multidistrict Litigation ..... 1288

B. Aggregation Minus a Monitor: Agency Costs as a

Bundling Problem .......................... 1291

II. Alternative Litigation Financing .............. 1300

A. A Taxonomy of Third-Party Financing ........... 1301

B. Mixed Litigation and Investment Incentives ........ 1304

1. Plaintiffs' Attorneys' Incentives ............. 1305

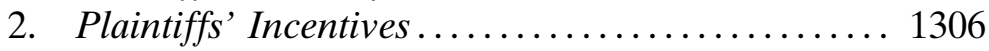

3. Financiers' Incentives .................... 1311

III. Financiers as Intermediaries ................. 1315

A. Revisiting the Missing Monitor Problem: Unbundling Agency from Financing ...................... 1315

1. Paying Plaintiffs' Attorneys on a Billable-Hour

System ............................. 1316

2. Splitting the Contingent Fee Between Financiers and Plaintiffs' Attorneys ................... 1318

3. Paying Plaintiffs' Attorneys for Their Billable

Hours Plus a Small Percentage of the Gross

Proceeds ................................. 1319

B. Decision-Making Control .................. 1320

C. The Litigation Financing Agreement ............. 1324

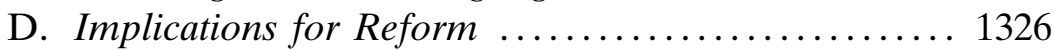

1. Augmenting Legal and Ethical Rules ......... 1326

2. Tailoring Judicial and Ethical Checks .......... 1330

3. Maintaining Horizontal Equity Among

Plaintiffs ............................. 1332

4. Taxing Free Riders ..................... 1333

IV. Costs, Benefits, and ObJections................ 1334

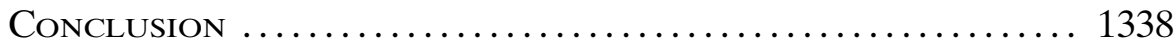

\section{INTRODUCTION}

Efforts aimed at extinguishing the class action have metastasized over the past fifteen years, culminating most recently in the Supreme Court's Wal-Mart Stores, Inc. v. Dukes opinion. ${ }^{1}$ Without class certification, aggregate litigation offers all of the perils and few of the

1 See 131 S. Ct. 2541, 2550-52 (2011) (strengthening the commonality requirement for class actions); see also Elizabeth Chamblee Burch, The New Dawn of Nonclass Aggregation, SCOTUSBlog (Apr. 6, 2012), http://www.scotusblog.com/2011/09/the-newdawn-of-nonclass-aggregation/ ("Consider, for example, the changes wrought over the past fifteen years by the Private Securities Litigation Reform Act, the Securities Litigation Uniform Standards Act, Amchem Products, Inc. v. Windsor, Ortiz v. Fibreboard Corp., and the Class Action Fairness Act, to name but a few."). 
promises of the class action. ${ }^{2}$ Granted, the class action posed problems too, ${ }^{3}$ but without its help in providing closure and the judge's role in ensuring a fair settlement, lawyers have dreamed up new means for achieving closure that evoke class-action nostalgia. For example, attorneys have exploited the attorney-client relationship by coercing clients into accepting a settlement, threatening to withdraw from representing nonconsenting clients, paying off holdouts to fulfill defendants' demands for complete resolution, forging ongoing "sweetheart" business relationships with settling defendants, and overcompensating weak but prevalent claims to attract more clients. ${ }^{4}$

The problem, in part, is that plaintiffs' attorneys play two, often conflicting roles: They serve as both financiers and agents. These dual roles can pull attorneys in divergent directions. Just as in class actions, lawyers front the costs of litigating massive cases. But these cases are even more expensive than class actions. Attorneys must spend time advertising and recruiting clients. Then, they must track each case, hire paralegals to handle the added paperwork, establish specific causation, and spend time persuading each client to settle. Add to that the cost of expert witnesses, investigation, document review, and coordinating with other multidistrict litigation attorneys, and the expenses could easily bankrupt a small firm. So when a defendant puts money on the table-even money with many strings attached-it tempts

2 "Aggregate litigation" is an umbrella term used when cases are handled jointly, whether solely for pretrial purposes through multidistrict litigation or formally joined through Rule 20 or consolidated through Rule 42. FED. R. CIV. P. 20, 42. "Multidistrict litigation" is a term used for cases that are brought individually, but transferred to a single judge for pretrial handling under the multidistrict litigation statute, 28 U.S.C. $\$ 1407$. Though the transfer is technically for pretrial purposes only, these cases rarely return to their original districts. See DeLaventura v. Columbia Acorn Trust, 417 F. Supp. 2d 147, 150-52 (D. Mass. 2006) ("[I]t is almost a point of honor among transferee judges acting pursuant to Section 1407 (a) that cases so transferred shall be settled rather than sent back to their home courts for trial.").

3 Agency problems in class actions have been frequently discussed. See, e.g., John C. Coffee, Jr., The Regulation of Entrepreneurial Litigation: Balancing Fairness and Efficiency in the Large Class Action, 54 U. CHI. L. Rev. 877, 882-84 (1987); Jonathan R. Macey \& Geoffrey P. Miller, The Plaintiffs' Attorney's Role in Class Action and Derivative Litigation: Economic Analysis and Recommendations for Reform, 58 U. CHI. L. Rev. 1, 7-8 (1991).

4 See, e.g., Johnson v. Nextel Commc'n, Inc., 660 F.3d 131, 139-40 (2d Cir. 2011) (describing an informal settlement guaranteeing plaintiffs' counsel $\$ 2$ million to work directly for the defendant as a consultant); see also Howard M. Erichson \& Benjamin C. Zipursky, Consent Versus Closure, 96 Cornell L. Rev. 265, 267-68 (2011) (describing how the Vioxx settlement required participating lawyers to withdraw from clients who refused the settlement agreement); Bruce Hay \& David Rosenberg, "Sweetheart" and "Blackmail" Settlements in Class Actions: Reality and Remedy, 75 Notre Dame L. Rev. 1377, 1390-91 (2000) (describing sweetheart settlements as agreements where the class counsel receives disproportionately large fees due to overlapping party incentives); infra Part I.B (detailing attorney-client agency problems). 
plaintiffs' attorneys to strong-arm their clients into settling. The attorneys can then recoup and profit from their financial investment. Because a client's and a lawyer's interests never overlap perfectly, the lawyer's monetary self-interest and duty of client loyalty may be at odds with one another and lead to a settlement that is not necessarily in the client's best interest. 5

Despite these problems, nonclass aggregation lacks a monitor to police these settlements the way a judge polices class actions. Although some judges have likened large multidistrict litigations to class actions and have tried to oversee them accordingly, ${ }^{6}$ the existence of a legal basis for policing a "voluntary" settlement between private parties is uncertain at best. Plus, the clients themselves are unlikely to monitor their attorney: The very aggregation that increases the economic viability of their claims fosters collective-action problems and makes it difficult to obtain meaningful information from their attorney. ${ }^{7}$ When cases are interdependent, learning the progress of one's own case may yield little information about the overall litigation and vice versa. Plus, individual plaintiffs tend to be unsophisticated about legal matters and to trust their attorney's advice- that is, after all, why they hired her. ${ }^{8}$

But the potential for a private monitor does exist in the unlikely guise of third-party financiers-hedge funds, private investors, and venture capitalists. Alternative litigation financing has gradually made its way from Australia and the United Kingdom into the United States, causing substantial controversy in the process. For example, the New York Times has run a critical series of articles titled Betting

5 See Geoffrey P. Miller, Some Agency Problems in Settlement, 16 J. Legal Stud. 189, 190 (1987) (explaining the conflicts of interest that may arise between attorneys and their clients).

6 For a discussion of cases in which judges have invoked their inherent authority to reduce fee awards in nonclass aggregate litigation, see infra notes 109-10 and accompanying text.

7 See Jack B. Weinstein, Individual Justice in Mass Tort Litigation 11-12 (1995) (explaining the extenuated attorney-client relationship in mass torts); Deborah R. Hensler, As Time Goes By: Asbestos Litigation After Amchem and Ortiz, 80 Tex. L. Rev. 1899, 1913 (2002) (noting the nontraditional attorney-client relationship in mass torts); Charles Silver, Ethics and Innovation, 79 GEo. WASH. L. REv. 754, 756 (2011) (explaining the extenuated attorney-client relationship in mass torts).

8 See Robert W. Gordon, The Independence of Lawyers, 68 B.U. L. REV. 1, 30 (1988) (observing that lawyers cannot help but influence their clients); Samuel Issacharoff \& Daniel R. Ortiz, Governing Through Intermediaries, 85 VA. L. Rev. 1627, 1639 (1999) (noting that monitoring may require specialized knowledge that average individuals do not possess); Russell Korobkin \& Chris Guthrie, Psychology, Economics, and Settlement: A New Look at the Role of the Lawyer, 76 Tex. L. REv. 77, 82 (1997) [hereinafter Korobkin \& Guthrie, Psychology] (observing that clients generally follow their attorney's advice). 
on Justice, ${ }^{9}$ the American Bar Association has convened a Commission on Ethics 20/20 Working Group on Alternative Litigation Financing, ${ }^{10}$ and the United States Chamber of Commerce recently issued a report titled Selling Lawsuits, Buying Trouble. ${ }^{11}$ Critics contend that alternative financing increases the number of lawsuits, particularly frivolous suits, and, in the aggregate litigation context, blackmails defendants into settling lawsuits regardless of the merits. $^{12}$

Despite this controversy, allowing third parties to fund nonclass aggregation helps to manage principal-agent problems by freeing attorneys from their financial self-interest and encouraging them to act as faithful agents. It does so by (1) unbundling the attorney's competing roles as investor and advisor, (2) shifting financial risk to a third party who pays the attorneys on a billable-hour basis (plus perhaps some small percentage of the recovery as a bonus), and (3) putting in place a sizeable stakeholder with the sophistication and incentive to monitor the agents. If plaintiffs assigned a financier a portion of the litigation's proceeds (as the contingent fee does now) in exchange for financing the lawsuit on a nonrecourse basis, the financier would become a super stakeholder.

Incentivizing a super stakeholder to monitor attorneys was the basic premise behind Elliott Weiss and John Beckerman's article, Let the Money Do the Monitoring: How Institutional Investors Can Reduce Agency Costs in Securities Class Actions. ${ }^{13}$ Weiss and Beckerman suggested that sophisticated institutional investors with the most at stake-and thus the greatest incentive to monitor class attorneys-

9 E.g., Binyamin Appelbaum, Betting on Justice: Putting Money on Lawsuits, Investors Share in the Payouts, N.Y. Times, Nov. 15, 2010, at A1 [hereinafter Appelbaum, Betting on Justice]; Binyamin Appelbaum, Lawsuit Loans Add New Risk for the Injured, N.Y. TIMEs, Jan. 17, 2011, at A1 [hereinafter Appelbaum, Lawsuit Loans]; Binyamin Appelbaum, Lobby Battle over Loans for Lawsuits, N.Y. Times, Mar. 10, 2011, at B1; Binyamin Appelbaum, Taking Sides in a Divorce, Chasing Profit, N.Y. Times, Dec. 5, 2010, at A1; see also Ashby Jones, The Next National Investment Craze: Lawsuits!, WALl ST. J. Blog (June 4, 2010, 12:36 PM), http://blogs.wsj.com/law/2010/06/04/the-next-national-investment-crazelawsuits/.

10 ABA Comm'n on Ethics 20/20, For Comment: Issues Paper Concerning Lawyer's Involvement in Alternative Litigation Financing (Nov. 23, 2010), available at http:// www.americanbar.org/content/dam/aba/migrated/ethics2020/alfposting.authcheckdam.pdf.

11 U.S. Chamber Inst. for Legal Reform, Selling Lawsuits, Buying Trouble: Third-Party Litigation Funding in the United States (2009).

12 Id. at 4-5.

13 Elliott J. Weiss \& John S. Beckerman, Let the Money Do the Monitoring: How Institutional Investors Can Reduce Agency Costs in Securities Class Actions, 104 YAle L.J. 2053 (1995). Their work led Congress to enact the Private Securities Litigation Reform Act of 1995, Pub. L. No. 104-67, 109 Stat. 737 (codified in scattered sections of 15 U.S.C.). S. REP. No. 104-98, at 11 n.32 (1995), reprinted in 1995 U.S.C.C.A.N. 679, 690. 
should serve as lead plaintiffs in securities class actions. Like institutional investors, financiers possess the legal acumen and financial impetus to act as intermediaries by negotiating better hourly rates and requiring attorneys to keep their costs reasonable. But unlike Weiss and Beckerman, I propose paying plaintiffs' attorneys on a billablehour basis to change their financial motivations; if a financier pushed for a quick settlement, the attorney's self-interest would counterbalance the financier's. The billable hour encourages the lawyer to prolong litigation and spend time advising her clients about the risks of litigating versus settling. Plus, it alleviates the concern over financial risk that may prompt attorneys to pressure their clients to settle.

Third-party financiers have already started funding aggregate litigation: Napoli Bern made headlines when it borrowed roughly $\$ 35$ million from Counsel Financial to fund the Ground Zero workers' personal injury cases against the City of New York and then tried to pass $\$ 6.1$ million in interest costs on to the workers. ${ }^{14}$ Burford Capital is currently funding thousands of Ecuadorian plaintiffs in their controversial personal injury battle against Chevron. ${ }^{15}$ Likewise, in a toxic tort case against BNSF Railway, attorney Jared Woodfill borrowed more than $\$ 3.5$ million from a hedge fund to help finance litigation on behalf of some 400 workers with skin and gastrointestinal cancers allegedly caused by chemicals used to make railroad ties. ${ }^{16}$ These financing arrangements, however, do not follow this Article's blueprint. Lending money to plaintiffs' law firms on a recourse basis, ${ }^{17}$ as was the case for Napoli Bern and Jared Woodfill, may either intensify the pressure on plaintiffs to settle or present them with unexpected interest charges. As this suggests, the way in which financiers bankroll aggregate litigation is critical; this new relationship raises a panoply of questions about maintenance, champerty, barratry, confidentiality, privileges, consent, decision-making authority, and incen-

14 Appelbaum, Betting on Justice, supra note 9; Joseph Goldstein \& Susan Edelman, Assembly Speaker Sheldon Silver's Firm Gets Cut of 9/11-Suit Payouts, N.Y. Post (Aug. 22, 2010), http://www.nypost.com/p/news/local/ill_heroes_must_shel_out_e1IBrP6PHVgTIR O7saJ3kM.

15 Lawrence Hurley, 'Master of Disaster' Dons New Guise as Plaintiffs' Attorney in Pollution Case, N.Y. Times (Feb. 1, 2011), http://www.nytimes.com/gwire/2011/02/01/ 01greenwire-master-of-disaster-dons-new-guise-as-plaintiff-74496.html?pagewanted=all; Roger Parloff, Have You Got a Piece of This Lawsuit?, CNN Money (June 28, 2011), http:/ /features.blogs.fortune.cnn.com/2011/06/28/have-you-got-a-piece-of-this-lawsuit-2/. There is an ironic link between the two cases: James Tyrrell, the plaintiffs' lawyer in the case against Chevron, defended New York City and contractors against 9/11 first responders' claims. See Hurley, supra.

16 Appelbaum, Betting on Justice, supra note 9.

17 When a lendor loans money on a recourse basis, the debtor must repay the loan regardless of whether the debtor wins or loses the lawsuit. 
tives. While scholars such as Richard Epstein, Keith Hylton, Jonathan Molot, Anthony Sebok, and Paul Rubin have written about the economic and ethical implications of third-party financing, ${ }^{18}$ neither economists, ethicists, nor complex litigation scholars have considered financing as a means for addressing the distorted lawyer-client relationship in mass litigation.

This Article focuses on the unique dynamics of funding mass litigation that proceeds outside of a class action and explains how uniting aggregate litigation with third-party financing can reduce agency costs. ${ }^{19}$ Part I.A first highlights the growing prevalence of nonclass aggregation, identifies how it affects plaintiffs' attorneys' risks and financial calculations, and notes its potential impact on substantive enforcement goals. Part I.B then chronicles the ways in which attorneys may act contrary to their principals' interests, through shirking or self-dealing. The circumstances of mass litigation exacerbate these unethical tendencies. Defendants continue to demand finality in exchange for settling, but plaintiffs' counsels' efforts to provide that finality and recover their financial investment outside the well-defined class-certification path can drive them to push the limits of professional responsibility. Despite these ethically questionable practices, there is little meaningful supervision over these settlements. Thus, Part I draws the link between contingent-fee financing, the incentives it creates for unethical behavior, and the lack of a supervising monitor in nonclass aggregate litigation.

Part II provides the relevant background on alternative litigation financing. It surveys the rise in third-party funding, demystifies the

18 See Jonathan T. Molot, Litigation Finance: A Market Solution to a Procedural Problem, 99 GEO. L.J. 65 (2010) (contending that third party financing may promote accuracy in adjudication and settlement); Anthony J. Sebok, The Inauthentic Claim, 64 VAND. L. REv. 61, 104-05 (2011) (arguing that historical doctrines like assignment and maintenance are not and should not be barriers to developing third-party litigation); Keith N. Hylton, The Economics of Third-Party Financed Litigation 27 (Aug. 2011) (unpublished manuscript), available at http://www.masonlec.org/wp-content/uploads/2011/07/HyltonRevised-Draft1.pdf (suggesting conditions under which third-party financing can enhance and reduce social welfare); Richard A. Epstein, The Costly Freedom To Sue, N.Y. Times (Mar. 3, 2011), http://www.nytimes.com/roomfordebate/2010/11/15/investing-in-someoneelses-lawsuit/the-costly-freedom-to-sue (questioning whether litigation financing will pressure defendants to settle on disadvantageous terms because of an inability to finance their defense); Paul H. Rubin, More Money into Bad Suits, N.Y. Times (Nov. 16, 2010), http:// www.nytimes.com/roomfordebate/2010/11/15/investing-in-someone-elses-lawsuit/moremoney-into-bad-suits (claiming that litigation in the United States is already excessive and that third-party financing will increase the number of lawsuits).

19 Because class actions include absent class members, they raise special concerns about notice and consent. This Article likewise does not address aggregate litigation in bankruptcy proceedings, such as asbestos, which raise similar concerns. 
various funding types, ${ }^{20}$ and unpacks the myriad of incentives that animate diverse financiers, plaintiffs, and their attorneys. Part II anticipates Part III.A, which explores the potential benefits of disentangling the attorney's role as case-financier from her obligations as a loyal advisor. Parts III.B and III.C, respectively, contemplate how to best allocate decision-making control and how to structure the litigationfinancing agreement. As evidenced by the Ground Zero and BNSF Railway litigations, nonconventional lenders can ensure continued access to justice for cases that are uneconomical to pursue individually. If these transactions are structured according to this Article's blueprint, they might likewise supply the oversight and attorney monitoring that nonclass aggregation lacks.

Allowing financiers to act as intermediaries that counterbalance agency problems requires some amendments to the existing regulatory landscape. Accordingly, Part III.D introduces three categories of regulatory changes to accompany this market-based solution: (1) administrative-regulatory solutions, (2) judicial forms of oversight, and (3) professional ethics constraints. First, administrative-regulatory solutions include extending the attorney-client privilege to cover financiers through the common interest doctrine, disclosing potential conflicts of interest between financiers and attorneys to clients, and substantively barring instruments that impose negative externalities on plaintiffs. Second, judicial oversight entails submitting the financing arrangement to the judge in camera to discourage unconscionable financing terms, excessive fee arrangements, and collusion between financiers and attorneys. Finally, augmenting professional ethics constraints involves relaxing historical bans on champerty, clarifying conflict-of-interest requirements for attorneys that seek out third-party financing, and loosening confidentiality protections to allow financiers to receive case-specific information.

As these changes suggest, third-party financing can introduce risks, too. These intermediaries add a new wrinkle that cures some principal-agent problems, but introduces others. Although financiers will have an incentive to monitor the attorneys, their incentives may not perfectly align with plaintiffs' interests. For instance, litigation that promotes social change by requesting injunctive and declaratory relief, as often occurs in Title VII and civil rights cases, may well be unattractive to investors who seek to maximize their returns. Part III.E considers these challenges and weighs these tradeoffs, but ultimately concludes that introducing third-party financing to aggregate

20 Such differences include those between consumer legal funding, loaning money to plaintiffs' law firms, and financing business versus business disputes. 
litigation can improve the status quo by closing the existing funding gap and by providing a much-needed monitor.

\section{I \\ The Prevalence and Costs of Aggregate Litigation}

Over the last fifteen years, the class-action landscape has shifted steadily. Since the mid-1990s, both Congress and the judiciary have curtailed class actions by providing federal courts with jurisdiction, ${ }^{21}$ requiring plaintiffs to prove Rule 23's prerequisites by a preponderance of the evidence, ${ }^{22}$ and making class certification more rigorous through a willingness to delve into the merits when they overlap with the certification requirements. ${ }^{23}$ Most recently, Wal-Mart Stores, Inc. v. Dukes strengthened the commonality standard under Rule 23(a) and ensured that defendants can raise individual defenses, which could inject individual issues into a class that might otherwise meet Rule 23(b)(3)'s predominance requirement. ${ }^{24}$ These changes have made certifying a class increasingly difficult. Consequently, an

21 The Class Action Fairness Act (CAFA), initially introduced in 1998 and in some form every year thereafter until it was passed in 2005, provides federal court jurisdiction over class actions by allowing defendants to remove a putative class worth $\$ 5$ million in the aggregate that has minimal diversity between the plaintiffs and the defendants. Class Action Fairness Act of $2005 \S 2$ (a), (b), Pub. L. No. 109-2, 119 Stat. 4, 5 (codified in scattered sections of 28 U.S.C.).

22 See, e.g., In re Hydrogen Peroxide Antitrust Litig., 552 F.3d 305, 307 (3d Cir. 2008) (allowing certification only if the plaintiffs establish Rule 23's requirements by a preponderance of the evidence); Oscar Private Equity Invs. v. Allegiance Telecom, Inc., 487 F.3d 261, 269 (5th Cir. 2007) (applying the preponderance of the evidence standard); In re Initial Pub. Offerings Sec. Litig., 471 F.3d 24, 41 (2d Cir. 2006) (holding that a court may certify a class only after it "resolves factual disputes relevant to each Rule 23 requirement"); Szabo v. Bridgeport Machs., Inc., 249 F.3d 672, 676 (7th Cir. 2001) ("Before deciding whether to allow a case to proceed as a class action, therefore, a judge should make whatever factual and legal inquiries are necessary under Rule 23.").

23 E.g., Hydrogen Peroxide Antitrust Litig., 552 F.3d at 307; Oscar, 487 F.3d at 268; Initial Pub. Offerings Sec. Litig., 471 F.3d at 41; Szabo, 249 F.3d at 676; see also PrinciPLes of the LAw OF AgGregate Litigation $\$ 2.06$ (2011) (stating that questions of fact relevant to the suitability of class-action treatment should be resolved by the preponderanceof-the-evidence standard).

24131 S. Ct. 2541, 2559-61 (2011). As Justice Scalia explained, under Title VII, "if the employer can show that it took an adverse employment action against an employee for any reason other than discrimination"-for instance, tardiness, poor customer service, false information on an application, or insubordination-"the court cannot order the "hiring, reinstatement, or promotion of an individual as an employee, or the payment to him of any backpay.' ' $I d$. at 2560-61. For previous cases noting that class certification could be proper despite the availability of individual affirmative defenses, see Smilow v. Sw. Bell Mobile Sys., Inc., 323 F.3d 32, 39-40 (1st Cir. 2003); Dupler v. Costco Wholesale Corp., 249 F.R.D. 29, 45-46 (E.D.N.Y. 2008); Aliotta v. Gruenberg, 237 F.R.D. 4, 12 (D.D.C. 2006). As for commonality, what matters now is not whether plaintiffs can raise common questions, but whether "a classwide proceeding [can] generate common answers apt to drive the resolu- 
increasing number of would-be classes now proceed en masse through multidistrict litigation and liberal joinder devices, such as Rules 20 and $42 .{ }^{25}$

This shift away from class actions leads to two concerns. First, because large class actions yield substantial plaintiffs' attorneys' fees, ${ }^{26}$ smaller classes and nonclass aggregation are more expensive, less lucrative, and thus less attractive business ventures. Aggregate lawsuits likewise require greater expenditures in client advertising and administrative costs. Funding an all-inclusive class action, particularly a Rule 23(b)(2) class where members cannot opt out, is more economical for plaintiffs' attorneys than filing thousands of individual claims. Aggregate litigation's increased cost means that fewer attorneys may enter the field, which could dampen competition among the plaintiffs' bar and may eventually affect the quality of the representation and the ability to sue. ${ }^{27}$ Moreover, because aggregate lawsuits are more expensive for plaintiffs' attorneys to initiate, fewer class actions may trigger an access to justice problem, undermine private enforcement efforts, and cause a market gap in litigation funding. As this section discusses, in the short term, these added expenses most likely mean that existing plaintiffs' firms with insufficient capital will look increasingly to third-party funders such as hedge funds and private investors to cover litigation costs. Alternative funding sources are controversial even in run-of-the-mill litigation, such as car accidents and other per-

tion of the litigation." Wal-Mart, 131 S. Ct. at 2559 (quoting Richard A. Nagareda, Class Certification in the Age of Aggregate Proof, 84 N.Y.U. L. Rev. 97, 132 (2009)).

25 Fed. R. Civ. P. 20, 42; see also Emery G. Lee III \& Thomas E. Willging, Impact of the Class Action Fairness Act on the Federal Courts: Preliminary Findings from Phase Two's Pre-CAFA Sample of Diversity Class Actions, 256 F.R.D. 214, 219 tbl.4 (2009) (showing a decline in class certification motions from seventy percent of cases in 1996 to just twenty-four percent in 2009); Thomas E. Willging \& Emery G. Lee III, From Class Actions to Multidistrict Consolidations: Aggregate Mass-Tort Litigation After Ortiz, 58 U. KAN. L. REv. 775, 793 (2010) ("In sum, the existing empirical evidence is consistent with the thesis that class certification has become less likely in the post-Ortiz period."). For more information on the differences between class actions and aggregate litigation, see generally Elizabeth Chamblee Burch, Procedural Justice in Nonclass Aggregation, 44 Wake Forest L. Rev. 1 (2009), where I describe the procedural justice problems that arise when aggregate litigation proceeds outside of the class action's protections.

26 Theodore Eisenberg \& Geoffrey P. Miller, Attorney Fees and Expenses in Class Action Settlements: 1993-2008, 7 J. Empirical Legal Stud. 248, 250 (2010).

27 See RAND Ctr. For Law \& Pub. Policy, Third-Party Litigation Funding \& Claim Transfer: Trends and Implications for the Civil Justice System 19 (2010), available at http://www.rand.org/pubs/conf_proceedings/2010/RAND_CF272.pdf ("Thirdparty funding has the potential to make some smaller firms contenders for large cases, which may, in turn, cause increased competition with larger firms."). 
sonal-injury cases. ${ }^{28}$ Not surprisingly, aggregate litigation compounds the controversy.

Second, as more cases proceed as nonclass aggregation, attorneys will continue to experiment with ethically questionable means for achieving litigation closure and recouping their financial investment. In mass torts, without the closure that class settlements once delivered, attorneys on both sides have turned to private contracts to achieve finality. These settlements regularly include walk-away provisions that allow defendants to withdraw their offers if too few claimants agree. ${ }^{29}$ And at least one has required participating plaintiffs' attorneys to recommend the deal to one hundred percent of their clients and withdraw from representing those who decline. ${ }^{30}$ Others add "bonus" payments if one hundred percent of the plaintiffs settle, thereby creating social pressure to achieve consensus. ${ }^{31}$ Consequently, the second part of this section chronicles these issues and the contingent-fee expenditures that fuel them.

\section{A. Funding Gaps and Fee Awards}

Private lawsuits are the principal vehicles for enforcing substantive rights in many areas like employment discrimination, securities fraud, products liability, consumer fraud, antitrust, and civil rights. ${ }^{32}$

28 E.g., Appelbaum, Lawsuit Loans, supra note 9, at A1 (criticizing the rise of alternative litigation financing).

29 See Paul H. Edelman et al., The Allocation Problem in Multiple-Claimant Representations, 14 Sup. Cт. ECON. Rev. 95, 101 (2006) (discussing the prevalence of walkaway provisions).

30 See Initial Settlement Agreement, In re Vioxx Prods. Liab. Litig., MDL No. 1657, If 1.2.8.1 (E.D. La. 2007), available at http://www.merck.com/newsroom/vioxx/pdf/Settlement _Agreement.pdf (including mandatory recommendation and withdrawal provisions). After some plaintiffs' attorneys contended the Vioxx settlement conflicted with ethical rules, the settlement agreement was clarified to suggest that the attorneys should recommend the deal only if it was in the client's best interest. Howard M. Erichson \& Benjamin C. Zipursky, Consent Versus Closure, 96 Cornell L. Rev. 265, 281 (2011); Alex Berenson, Some Lawyers Seek Changes in Vioxx Settlement, N.Y. Times (Dec. 20, 2007), http:// www.nytimes.com/2007/12/20/business/20cnd-vioxx.html. For an overview of how these provisions exert ethical pressure on plaintiffs' counsel, see Howard M. Erichson, The Trouble with All-or-Nothing Settlements, 58 U. KAN. L. REv. 979 (2010).

31 See Mireya Navarro, Deal Is Reached on Health Costs of 9/11 Workers, N.Y. TIMEs, Mar. 12, 2010, at A1 [hereinafter Navarro, Health Costs of 9/11] (describing the bonus arrangement found in the Ground Zero settlement).

32 I proceed from the notion that most aggregate litigation begins on a good faith basis. While the occasional bad faith lawsuit may still exist, there are substantial barriers to initiating meritless litigation such as the hefty costs of initiating and pursuing large-scale litigation, exacting pleading standards, and Rule 11 which imposes sanctions on attorneys who initiate frivolous lawsuits. See generally Elizabeth Chamblee Burch, CAFA's Impact on Litigation as a Public Good, 29 CARdozo L. REv. 2517, 2520-23 (2008) (claiming that class actions can be a public good) [hereinafter Burch, CAFA's Impact]; Elizabeth Chamblee 
They provide a failsafe for agency capture and a check on government abuse and political overreaching. ${ }^{33}$ As the courts and Congress have steadily curtailed the plaintiffs' bar's ability to pursue these cases as class actions, they have affected the means of enforcing a wide range of civil rights, complex statutory schemes, and constitutional rights that past courts willingly certified as Rule 23(b)(2) class actions. ${ }^{34}$ For example, district and appellate courts have already relied on the reasoning in Wal-Mart Stores, Inc. v. Dukes to decertify or decline to certify toxic tort cases, ${ }^{35}$ environmental law cases, ${ }^{36}$ product liability cases, ${ }^{37}$ breach of contract claims, ${ }^{38}$ and Truth in Lending Act claims. ${ }^{39}$

Although it is difficult to predict exactly how these changes will affect substantive enforcement goals, if the history of mass torts is indicative, it illustrates the adaptability and flexibility of the plaintiffs' bar..$^{40}$ Rather than evaporating with the mass-tort class action, plaintiffs' attorneys have moved into nonclass aggregation. Product liability multidistrict litigations from 2004 to 2008 involved 1832 different law firms, and the Vioxx litigation alone involved 1100 law firms. ${ }^{41}$ While

Burch, Securities Class Actions as Pragmatic Ex Post Regulation, 43 GA. L. Rev. 63 (2008) (contending that securities class actions play a beneficial role in society).

33 John C. Coffee, Jr., Litigation Governance: Taking Accountability Seriously, 110 Colum. L. Rev. 288, 345 (2010).

34 E.g., Davis v. Coca-Cola Bottling Co. Consol., 516 F.3d 955, 961 (11th Cir. 2008) (litigating employment discrimination claims); Bolton v. Murray Envelope Corp., 553 F.2d 881 (5th Cir. 1977) (same); Woodard v. Online Info. Servs., 191 F.R.D. 502 (E.D.N.C. 2000) (litigating Fair Debt Collection Practices Act violations); Irwin v. Mascott, 96 F. Supp. 2d 968 (N.D. Cal. 1999) (same).

35 E.g., Opinion and Order of the Court Denying Class Certification, Henry v. Dow Chem. Co., No. 03-47775-NZ, 2011 WL 3269118, at*2-5 (Mich. Cir. Ct. July 18, 2011).

36 E.g., Gates v. Rohm \& Haas Co., 655 F.3d 255, 274 (3d Cir. 2011).

37 E.g., In re Bisphenol-A (BPA) Polycarbonate Plastic Prods. Liab. Litig., 276 F.R.D. 336, 344 (W.D. Mo. 2011).

38 E.g., Altier v. Worley Catastrophe Response, LLC, Nos. 1-241, 11-242, 2011 WL 3205229 (E.D. La. July 26, 2011).

39 E.g., Haynes v. Planet Automall, Inc., 276 F.R.D. 65 (E.D.N.Y. 2011).

40 Still, some of these cases are likely to disappear from litigation entirely: for instance, claims that defendants can avoid through arbitration agreements, like consumer fraud claims and at least some employment disputes. Although public agencies like the SEC, DOJ, and EEOC can avoid the problems with complying with Rule 23, they may not be able to obtain the full monetary remedies available to private plaintiffs. See, e.g., Jefferson v. Ingersoll Int'l Inc., 195 F.3d 894, 899 (7th Cir. 1999) (noting that the EEOC may not request the same relief that private plaintiffs request, including the full extent of monetary relief). This Article focuses on the alternative problem of nonclass aggregation.

41 Affidavit of Joshua D. Wright, Memorandum in Support of Motion for Reconsideration/Revision of Order Capping Contingency Fees and Alternatively for Entry of Judgment, at 10-11, In re Vioxx Prods. Liab. Litig., MDL No. 1657 (E.D. La. Dec. 10, 2008) (on file with the New York University Law Review); Charles Silver \& Geoffrey P. Miller, The Quasi-Class Action Method of Managing Multi-district Litigations: Problems and a Proposal, 63 VAnd. L. Rev. 107, 138 (2010). 
this suggests that enforcement options remain for individually marketable claims, the move away from class action puts additional pressure on the agency relationship by adding expense and circumventing welltraveled paths for achieving wholesale resolution. That pressure continues to bedevil mass-tort litigation, and with the tightening of class remedies across the board, it is likely to spread to group-based litigation in other substantive areas as well.

Entrepreneurial private attorneys typically do not work for free. Instead, they rely on either congressionally approved fee-shifting statutes or contingent fees to compensate them. The contingent fee is the usual method for remunerating plaintiffs' attorneys in areas like mass torts, ${ }^{42}$ whereas Congress authorizes fee-shifting statutes in civil rights litigation, such as the Age Discrimination in Employment Act, Title VII, and the Americans with Disabilities Act. ${ }^{43}$

In class actions, judges typically employ the percentage of the common fund method for calculating reasonable contingent-fee awards and the lodestar method under fee-shifting statutes. ${ }^{44}$ Empirical studies, however, have consistently shown that the size of the class's recovery is the "overwhelmingly important determinant" of the fee award, regardless of which test courts use. ${ }^{45}$ When class actions were commonplace, few plaintiffs ever opted out-which meant that when courts awarded attorneys' fees based on client recovery, plaintiffs' attorneys tended to receive higher awards. ${ }^{46}$ Although all mass litigation is expensive, tightening class certification standards means more risk and less reward for plaintiffs' lawyers. The current eco-

42 For background on the economics of contingency fees, see generally Albert H. Choi, Allocating Settlement Authority Under a Contingent-Fee Arrangement, 32 J. Legal Stud. 585 (2003), and Rudy Santore \& Alan D. Viard, Legal Fee Restrictions, Moral Hazard, and Attorney Rents, 44 J. L. \& ECON. 549 (2001).

43 Age Discrimination in Employment Act of 1967, 29 U.S.C. $\$ 626$ (b) (2006); Civil Rights Attorney's Fees Awards Act of 1976, 42 U.S.C. $\S 1988$ (b) (2006); Title VII of the Civil Rights Act of 1964, 42 U.S.C. $§ 2000 \mathrm{e}-5(\mathrm{k})$ (2006); Americans with Disabilities Act of 1990, 42 U.S.C. $\S 12205$ (2006).

44 See, e.g., Staton v. Boeing Co., 327 F.3d 938, 965 (9th Cir. 2003) (using the lodestar method to award reasonable fees under a fee-shifting statute). Courts employing the lodestar method multiply a reasonable number of attorney hours by a reasonable hourly rate and then use various factors to adjust the final rate. See Gisbrecht v. Barnhart, 535 U.S. 789 (2002); Charles Silver, Due Process and the Lodestar Method: You Can't Get There from Here, 74 Tul. L. REv. 1809 (2000) (discussing problems with the lodestar method). On feeshifting statutes generally, see Note, State Attorney Fee Shifting Statutes: Are We Quietly Repealing the American Rule?, 47 LaW \& Contemp. Probs. 321, 322-23 (1984).

45 Eisenberg \& Miller, supra note 26, at 250.

46 See Theodore Eisenberg \& Geoffrey P. Miller, Attorney Fees in Class Action Settlements: An Empirical Study, 1 J. EmPirical Legal Stud. 27, $28-29$ (2004) ("We find that the level of client recovery is by far the most important determinant of the attorney fee amount."). 
nomic climate only exacerbates the problem: Law firms are unable to pay their own expenses, much less take on years of litigation without a payday in sight. ${ }^{47}$

\section{The Financial Risks of Aggregate Litigation}

This section first considers the financial risks involved for plaintiffs' attorneys in all large-scale litigation, then the specific challenges that multidistrict litigation adds. To initiate aggregate litigation, attorneys must develop both "generic" and "specific" assets. ${ }^{48}$ Generic assets include things like expert witnesses and discovery documents that establish general causation and apply broadly to the attorney's portfolio of similarly situated clients. A simple failure-to-warn claim requires understanding how much the medical community knew about the risk before a plaintiff could ever demonstrate that the defendant breached its duty. ${ }^{49}$ And this requires experts, document review, witness interviews, and extensive timelines about who knew what and when. ${ }^{50}$ These assets are particularly risky to develop, given that other lawyers could free-ride on one attorney's investment. Specific assets, on the other hand, include the substantial expense of developing the facts of each client's case as well as proving specific causation-that the product caused this plaintiff's injury or that an employer discriminated against this employee. ${ }^{51}$

Developing these assets takes substantial time and capital. Investments can take years to recoup, which means that plaintiffs' law firms might have to pool their resources, borrow funds from banks, or, as explored in Part III, request financing from third parties. ${ }^{52}$ Back in 1995, attorney Michael Pretl, who sued A.H. Robbins in the Dalkon Shield litigation, reported: "We handled over 1,000 Dalkon cases, and it took 20 years before we showed a profit .... We borrowed heavily at high interest rates to finance the litigation. Even though we settled

47 As one law firm's founding partner explained in the process of going out of business, "It's a sign of the current times. Banks are getting a lot more nervous with law firm finance and are pulling loans more quickly." Ben Moshinsky, Focus: Orchard Solicitors, Til Debt Do Us Part, TheLawyer.com (Mar. 16, 2009), http://www.thelawyer.com/focus-orchardsolicitors-til-debt-do-us-part/137154.article.

48 See Richard A. Nagareda, Mass Torts in a World of Settlement 13-14 (2007).

49 Id. (discussing plaintiffs' attorneys' generic assets).

50 See id. at 13.

51 See id.; see also Stephen C. Yeazell, Brown, the Civil Rights Movement, and the Silent Litigation Revolution, 57 VAND. L. REv. 1975, 1194 (2004) ("[I]n lawsuits, law is relatively cheap, but facts are typically expensive.").

52 See Nagareda, supra note 48, at 14. 
\$55 million in claims, this will be the first year we'll be in the black." 53 Vioxx is a more recent example. One plaintiffs' lawyer estimated that a single Vioxx case initially cost between $\$ 1$ million and $\$ 1.5$ million to develop. ${ }^{54}$ But once the attorneys turned their collective wisdom into trial packages and put the infrastructure in place, others could litigate similar cases for around $\$ 200,000$, thereby creating a disincentive to develop early cases..$^{55}$

Creative financing schemes that help cover and disperse these costs are nothing new. After spending more than $\$ 3$ million on the Agent Orange litigation in the mid-1980s, the plaintiffs' attorneys could not afford to continue litigating. ${ }^{56}$ To avoid dismissing the case, a reconstituted Plaintiffs' Management Committee allowed six of the nine members to advance funds toward developing generic assets, with each dollar the "investor-attorney" funded repaid threefold if plaintiffs prevailed-a 300\% return. ${ }^{57}$ Judge Weinstein and the Second Circuit reached conflicting outcomes as to the arrangement's permissibility. ${ }^{58}$ Judge Weinstein insisted that the Committee increase the decision-making authority of the lawyers working on the case, as opposed to those just investing in it, but he sidestepped any ethical dilemmas by viewing the Committee as "an ad hoc law firm." 59 Because the Committee shared traditional attorneys' obligations of loyalty and confidentiality to class members and "served only to redistribute attorneys' fees," not to reduce client benefits, the only danger was that "investor" members might clamor to settle early in order to recoup their investment. ${ }^{60}$ The Second Circuit, on the other hand, disagreed with the law firm analogy, found that the agreement created impermissible conflicts of interest between the investor-attorneys and the class, and invalidated the agreement. ${ }^{61}$

53 Gregory C. Baumann, Wanted: Law Firm with Guts, The Daily Record, Nov. 17, 1995 , at 1 .

54 Joe Nocera, Forget Fair; It's Litigation as Usual, N.Y. Times (Nov. 17, 2007), http:// www.nytimes.com/2007/11/17/business/17nocera.html?pagewanted=all.

55 See id.

56 Jack B. Weinstein, Individual Justice in Mass Tort Litigation 77 (1995).

57 Vincent Robert Johnson, Ethical Limitations on Creative Financing of Mass Tort Class Actions, 54 Brook. L. Rev. 539, 549-50 (1988).

58 See In re "Agent Orange" Prod. Liab. Litig., 818 F.2d 216, 218 (2d Cir. 1987) (invalidating the agreement), rev'd, In re "Agent Orange" Prod. Liab. Litig., 611 F. Supp. 1452, 1453 (E.D.N.Y. 1985) (upholding the agreement).

59 Weinstein, supra note 56, at 77; see also In re "Agent Orange," 611 F. Supp. at 1461-62 (considering a number of factors in favor of authorizing the agreement).

60 Weinstein, supra note 56, at 77-78; see also In re "Agent Orange," 611 F. Supp. at 1460-61 (discussing incentives toward early settlement).

61 In re "Agent Orange," 818 F.2d at 225-26; Johnson, supra note 57, at 553. 


\section{The Added Risks of Multidistrict Litigation}

Nonclass aggregation presents an additional set of risks for plaintiffs' attorneys that militates in favor of creative financing. First, these lawyers are forced to take on substantial administrative costs. In nonclass aggregation, attorneys recruit and interact with individual clients, which is significantly more expensive than interacting with a few class representatives and receiving fees based on benefiting the whole class. ${ }^{62}$ For instance, attorneys in the Vioxx Litigation Consortium considered 30,000 potential clients and accepted only 2000-a process which took a combined 1,601,150 hours by staff, paralegals, attorneys, nurse practitioners, and medical experts at a cost of $\$ 13.5$ million. ${ }^{63}$

Second, multidistrict litigation increases coordination costs and decreases attorney control. Although class-action attorneys must often coordinate among large legal teams within their firms and occasionally jockey with other attorneys to become class counsel, multidistrict litigation significantly alters these dynamics. Coordination typically occurs both informally and formally. Informally, plaintiffs' attorneys may form groups and coalitions on their own, such as the Vioxx Litigation Consortium (which included lawyers from five law firms) and the Polybutylene Plumbing Litigation (which included lawyers from forty-nine law firms). ${ }^{64}$ Formally, judges handpick experienced attorneys to serve on executive committees, plaintiffs' steering committees, and specialized committees. ${ }^{65}$ These formal and informal aspects often meld. For example, plaintiffs' attorneys selected Chris Seeger and Andy Birchfield as co-lead attorneys for the Vioxx Plaintiffs' Steering Committee over an informal dinner at Antoine's in New Orleans; thus, it was a foregone conclusion when Judge Fallon subsequently formally appointed them to the position. ${ }^{66}$ This selection process relegates disfavored attorneys to a secondary status, renders them unable to control their cases, and decreases their compensation. ${ }^{67}$

62 See Joshua Hamerman, A PE Fund To Sponsor Corporate Litigation, Investment Dealers' Dig., Jan. 22, 2010, at 1, 17 ("In the U.K. [where class actions are opt-in], you ... need to literally recruit claimants one by one; as a result the administrative costs can become very large relative to the action.").

63 Silver \& Miller, supra note 41, at 128.

64 In re Polybutylene Plumbing Litig., 23 S.W.3d 428, 432 (Tex. App. 2000); see also Silver \& Miller, supra note 41, at 126 (discussing these ad hoc consortiums).

65 See Dennis E. Curtis \& Judith Resnik, Contingency Fees in Mass Torts: Access, Risk, and the Provision of Legal Services When Layers of Lawyers Work for Individuals and Collectives of Clients, 47 DePaul L. Rev. 425, 431 (1998) (observing that plaintiffs' steering committees might be self-selected through colleagues or through designation by a judge).

66 Snigdha Prakash, All the Justice Money Can Buy 13-14 (2011).

67 Silver \& Miller, supra note 41, at 118-20. 
Third, multidistrict litigation means less certain fee awards than in individual cases or class actions. In individual contingent-fee cases, clients sign retainer agreements allocating their attorney around thirty-three percent of the litigation's proceeds. ${ }^{68}$ In class actions, judges award attorneys' fees based on the percentage of the common fund method (often with a lodestar check), which ranges from eleven to thirty-nine percent, with an average of around twenty percent. ${ }^{69}$ But backroom jockeying for key positions, judicial creation of and appointment to various litigation committees, ad hoc fee cuts, and the comparative lack of transparency and certainty with regard to judicial intervention make multidistrict litigation a riskier venture. ${ }^{70}$ Even though clients involved in multidistrict litigation have individually retained their attorneys and thus have agreed to set contingent fees, some judges reduce and reallocate those fees to compensate attorneys performing common-benefit work and to minimize plaintiffs' litigation costs. ${ }^{71}$

For example, the fee cap in the Guidant litigation meant that lawyers on the case's outskirts-whose clients had agreed to a forty percent contingent fee-received only twenty-eight percent of their clients' gross recovery. ${ }^{72}$ Even the "chosen" lawyers on key committees are not safe from this uncertainty, as the recent Vioxx skirmish over $\$ 350$ million in common-benefit fees demonstrated. ${ }^{73}$ Divvying

68 See Herbert M. Kritzer, The Wages of Risk: The Returns of Contingency Fee Legal Practice, 47 DePaul L. Rev. 267, 285-86 (1998) (discussing characteristics of contingency fees).

69 See Eisenberg \& Miller, supra note 26, at 258 (studying class-action awards from 1993 to 2008 and observing that "[t]he mean fee to recovery ratio was 0.23 , or 23 percent of the class award, but this percent varies by recovery size"); Brian T. Fitzpatrick, $A n$ Empirical Study of Class Action Settlements and Their Fee Awards, 7 J. EMPIRICAL Legal STUD. 811, 831 (2010) (finding that fees and expenses averaged twenty percent of total settlement amounts in 2007).

70 "[T]rial judges may also appoint lead counsel and plaintiff steering committees, transforming these attorneys into lawyers for a group, albeit lawyers with an even less defined set of ethical obligations than the class action lawyer." Judith Resnik, Aggregation, Settlement, and Dismay, 80 Cornell L. Rev. 918, 931 (1995). See Charles Silver, The Responsibilities of Lead Lawyers and Judges in Multidistrict Litigations, 79 FORDHAM L. REV. 1985, 1986-87 (2011) (discussing the ways in which steering committees control multidistrict litigation and the little control plaintiffs have over lead attorneys).

71 See Silver \& Miller, supra note 41, at 139 (discussing fee caps imposed on "disabled lawyers").

72 In re Guidant Corp. Implantable Defibrillators Prods. Liab. Litig., MDL No. 051708, 2008 WL 3896006, at *10 (D. Minn. Aug. 21, 2008) (involving a large-scale multidistrict litigation that Judge Frank dubbed a quasi-class action); see also Silver \& Miller, supra note 41, at 129-30 (discussing fee allocation problems in multidistrict litigations).

73 When a judge appoints common-benefit counsel to perform work for the benefit of all plaintiffs involved in a multidistrict litigation those attorneys' fees are often called "common-benefit fees." 
up that money required a special committee, a discovery master, rounds of objections, a weeklong hearing, and, ultimately, a 132-page court order. ${ }^{74}$

The same uncertainty plagued plaintiffs' lawyers in the Ground Zero workers case. Judge Hellerstein cut their fees from the contractual amount of thirty-three percent to twenty-five percent, and prohibited them from charging clients some $\$ 6.1$ million in interest costs from third-party financing. ${ }^{75}$ Moreover, when more than ninety-five percent of plaintiffs consented to the proposed settlement, thereby swelling the compensation from $\$ 625$ million to $\$ 680$ million, Judge Hellerstein forbade their lawyers from sharing in the increase. He explained, "Such fees, taken after plaintiffs' counsel have had all their expenses paid out of the settlement funds, are more than sufficient to compensate counsel for their representation."76 Plaintiffs' lawyers, not surprisingly, considered appealing the ruling. One lead attorney explained, "We should be paid because it was part of the deal," and noted that the bonus payments were "something we had to litigate."77

Of course, in some ways, hindsight makes it easy to cut fees and to contend that plaintiffs' attorneys are overcompensated, particularly when some benefit greatly from others' efforts and from economies of scale. Still, litigation's risks and rewards cannot be measured in a single case; instead, lawyers tend to think of contingent-fee cases as a portfolio of risk. ${ }^{78}$ Diversifying cases diversifies risk, such that the winning cases finance not only their own costs, but the costs of the losing cases as well. ${ }^{79}$ It is this insurance-like dimension of spreading risk across clients that judges may fail to appreciate.

Because diversification among clients and cases is easier in individual litigation, attorneys who practice in aggregate litigation often turn to creative financing arrangements to spread risk. Historical doctrines like champerty and barratry would ban not only these arrangements but also class actions, because they promote "officious intermeddling in a suit that ... belongs to [no] one" and "excit[e] and

74 In re Vioxx Prods. Liab. Litig., 802 F. Supp. 2d 740 (E.D. La. 2011); Alison Frankel, Vioxx Judge Steps in To Split \$350 Ml Plaintiffs Lawyer Pie, Reuters (Aug. 11, 2011), http://blogs.reuters.com/alison-frankel/2011/08/11/vioxx-judge-steps-in-to-split-350-mlplaintiffs-lawyer-pie/.

75 See Mark Hamblett, Plaintiffs' Lawyers in 9/11 Cases Lose Bid To Recoup Interest Costs, N.Y. L.J., Aug. 30, 2010, at 1.

76 Mireya Navarro, Terms Met, Payout Rises for Workers at 9/11 Site, N.Y. Times, Sept. 13, 2011, at A28 [hereinafter Navarro, Terms Met].

77 Id.

78 See Herbert M. Kritzer, Risks, Reputations, and Rewards 10-19 (2004) (comparing contingent-fee practice to portfolio management).

79 Id. at 16. 
stir[ ] up suits and quarrels." 80 But concerns about deterring wrongdoing and equitably compensating large plaintiff groups have long trumped these antiquated deontological and professional concerns. ${ }^{81}$ Eliminating old bars against contingent-fee arrangements and compensating class counsel based on common fund and restitutionary theories encourage non-governmental lawyers to act on behalf of plaintiffs who lack the economic incentive or funding to sue. ${ }^{82}$ Although the legal system is no longer concerned about exciting and stirring up mass litigation, using the contingent fee to compensate plaintiffs' attorneys has led to a new concern: It can distort incentives in the lawyer-client relationship.

\section{B. Aggregation Minus a Monitor: Agency Costs as a Bundling Problem}

Contingent fees augment the lawyer-client relationship by making the attorney the financier. She is an agent, a creditor, an investment banker, and a risk manager; the litigation is a joint venture with the client. ${ }^{83}$ But bundling these two roles-financier and advisor-breeds attorney-client conflicts of interest. To be sure, other billing arrangements create perverse incentives too. Hourly billing incentivizes attorneys to work slowly and to prolong lawsuits by filing unnecessary motions. And even pro bono services may encourage attorneys to skimp on research and development so that they can return to paying clients. But contingent fees spawn nearly all the quintessential agency problems in aggregate litigation. ${ }^{84}$ As Judge Weinstein observed after handling the Agent Orange, asbestos, and diethylstilbestrol (DES) cases, most mass-tort lawyers are "focused on

804 William Blackstone, Commentaries *134-35.

81 These concerns about deterring wrongdoing and equitably compensating plaintiffs, particularly in the civil rights context, led to the enactment of Rule 23. FED. R. CIV. P. 23(b)(2) advisory committee's note.

82 See Boeing Co. v. Van Gemert, 444 U.S. 472, 478-79 (1980) (discussing the history of the common fund doctrine); Charles Silver, A Restitutionary Theory of Attorneys' Fees in Class Actions, 76 Cornell L. Rev. 656, 663-66 (1991) (contending that the restitutionary theory supports the payment of attorneys who win class actions).

83 See Kutak Symposium: Professional Responsibility and the Corporate Lawyer, 13 Geo. J. Legal Ethics 331, 340-41 (2000) (observing the same phenomenon in the classaction context); Charles Silver, Merging Roles: Mass Tort Lawyers as Agents and Trustees, 31 Pepp. L. Rev. 301, 302-03 (2003) (positing that in mass-tort representations, as in class actions, "[t]he plaintiffs' attorneys provide crucial financing").

84 For background on the principal-agent problems with contingency fees, see generally James D. Dana, Jr. \& Kathryn E. Spier, Expertise and Contingent Fees: The Role of Asymmetric Information in Attorney Compensation, J.L. ECON. \& ORG. 349 (1993); Miller, supra note 5; A. Mitchell Polinsky \& Daniel L. Rubinfeld, Aligning the Interests of Lawyers and Clients, 5 Am. L. \& Econ. Rev. 165 (2003). 
getting cash for the individual client, obtaining a large fee, and closing the file as quickly and with as little effort as possible." 85

Contingent fees are less problematic in individual and class litigation. In individual litigation, a plaintiff can monitor the attorney herself. Although she may lack the expertise to evaluate legal arguments and motions, she can insist on explanations from the attorney, request additional information, and determine whether the attorney's performance conforms to her expectations. Because class members are typically uninvolved in class actions, Rule 23 imposes fiduciary duties on the attorney to act in the whole class's best interest and requires the judge to certify that the attorney adequately represents the class; to ensure that any settlement is fair, reasonable, and adequate; and to approve attorneys' fee requests. ${ }^{86}$ Nonclass aggregation, however, lacks these monitoring options. Clients are disaggregated, and a single attorney often represents hundreds or thousands of clients with roughly similar claims, making meaningful client monitoring difficult. ${ }^{87}$ Because judges do not certify plaintiffs' claims as a class, the judge has far less authority to police the agency relationship and the settlement.

My point is not that all or even most plaintiffs' attorneys are unethical, but that the current incentive structure is open to abuse in nonclass aggregation. Paying attention to situations in which attorneys' interests diverge from their clients' interests and eliminating some sources of tension can foster fidelity and loyalty. This section describes the theoretical situations in which an attorney's interests might diverge from her client's and provides illustrative, anecdotal evidence of questionable practices. ${ }^{88}$

85 Weinstein, supra note 56, at 49-50.

86 Fed. R. Civ. P. 23. For a discussion of the trial judge as a fiduciary for nonparticipating class members, see also Reynolds v. Beneficial Nat'l Bank, 288 F.3d 277 (7th Cir. 2002); Nancy Morawetz, Bargaining, Class Representation, and Fairness, 54 Онго Sт. L.J. 1 (1993); Chris Brummer, Note, Sharpening the Sword: Class Certification, Appellate Review, and the Role of the Fiduciary Judge in Class Action Lawsuits, 104 Colum. L. Rev. 1042, 1060-62 (2004).

87 As others and I have suggested, a plaintiffs' steering committee-made up of the claimants, not their attorneys-might also perform a monitoring function. See Elizabeth Chamblee Burch, Litigating Together: Social, Moral, and Legal Obligations, 91 B.U. L. Rev. 87, 126 (2011) [hereinafter Burch, Litigating Together]; Silver, supra note 7, at 759. The catch is that, for procedural justice purposes, the plaintiffs themselves must still have the opportunity to play a role in group deliberation. See Burch, supra, at 126 \& n.173.

88 Of course, these examples may come from outlier cases and may not reflect business as usual. The point is to lend context to the analytical observation that the incentive structure is open to abuse, not to suggest that these examples are the norm. There are few empirical studies on disciplinary violations that offer hard evidence of these practices, and many violations remain unreported. One study that does exist did not specifically examine aggregate litigation or class actions, but demonstrated a high percentage of disciplinary 
1. Quick Settlement Sell-Outs. The tangled advisor-lender relationship may motivate attorneys to settle quickly and cheaply if doing so allows them to collect their contingent fees and to move on to other cases. ${ }^{89}$ If a defendant offers to settle a case for a nominal value soon after receiving a complaint, the plaintiff's attorney might prefer to accept the offer because she would receive her fee and then be free to litigate other cases, even if further work on the case might yield a marginally higher value for her client. ${ }^{90}$ For example, suppose the attorney thinks that working on the case for another year might produce a settlement offer that is $\$ 300,000$ more than the current offer, but that the additional year of work would cost her $\$ 150,000$. Assuming a one-third contingent fee, she would receive only $\$ 100,000$ as compensation for the $\$ 150,000$ of additional work. The attorney would prefer to accept the initial settlement offer, but the clients might want her to press forward, since their settlement value would be greater. Thus, the attorney's loyalty is divided between her selfinterest and her clients' interests.

2. Collusive Settlements. A close cousin of the quick settlement, collusive settlements may occur because plaintiff and defense attorneys are often repeat players. ${ }^{91}$ Knowing that they will meet again, they may adjust their litigation tactics and settlements to reflect past interactions and future negotiations rather than the present case's merits. ${ }^{92}$ Because developing case-specific expertise is costly, both plaintiff and defense attorneys specialize. For instance, a handful of repeat-player law firms usually handle the majority of mass-tort or employment-discrimination cases. ${ }^{93}$ Consider the Dalkon Shield litiga-

violations among plaintiff-side personal injury attorneys. See Patricia W. Hatamyar \& Kevin M. Simmons, Are Women More Ethical Lawyers? An Empirical Study, 31 Fla. St. U. L. REv. 785, 818 \& tbl.12 (2004) ("[T]he types of legal matters in which disciplinary violations were most often found in our sample were domestic relations $(20 \%)$, personal injury representing the plaintiff (19\%), and criminal defense (14\%).").

89 See Silver, supra note 83, at 306-07.

90 See Miller, supra note 5, at 190.

91 See Marc Galanter, Why the "Haves" Come Out Ahead: Speculations on the Limits of Legal Change, 9 Law \& SoC'y REv. 95, 97-103 (1974) (discussing problems with repeat players).

92 See KRITZER, supra note 78, at 15 (describing lawyers' management of risk); Edward H. Cooper, Aggregation and Settlement of Mass Torts, 148 U. PA. L. Rev. 1943, 1951-52 (2000) (noting that the presence of repeat players may lead to "results . . similar to the problem of "regulatory capture'"); $c f$. Amchem Prods., Inc. v. Windsor, 521 U.S. 591, 625-28 (1997) (reasoning that the goal of injured plaintiffs to maximize their payout "tugs against the interest" of class members who are asymptomatic - to preserve funds for future payment). For a discussion of related problems in the class action context, see Hay \& Rosenberg, supra note 4, at 1390-91.

93 See John C. Coffee, Jr., Class Wars: The Dilemma of the Mass Tort Class Action, 95 Colum. L. Rev. 1343, 1364 (1995). 
tion: Six attorneys represented 8039 claimants (an average of 1340 each), and forty-three attorneys represented the remaining 13,174 claimants. ${ }^{94}$ Likewise, only a handful of plaintiffs' law firms represented asbestos plaintiffs, ${ }^{95}$ and asbestos defense attorneys organized a single consortium to negotiate a settlement. ${ }^{96}$ Their negotiations resulted in a complaint, answer, joint motion for conditional class certification, and proposed settlement all being filed within a single day. ${ }^{97}$ Although the trial court approved the settlement agreement, the Supreme Court famously reversed, in part, because the plaintiffs' attorneys struck a better deal for their present inventory of clients than for those with diseases that would manifest in the future. ${ }^{98}$

Class actions contain built-in protections that help to guard against collusion: Judges must review class settlements for fairness, reasonableness, and adequacy; class objectors can object to unfair terms and attorneys' fees; and state attorneys general can intervene and object. ${ }^{99}$ Nonclass aggregation, on the other hand, lacks these safeguards.

3. Underfunded Litigation. Given aggregate litigation's expense, a real danger exists that the contingent-fee attorney may run out of resources with which to prosecute the case. Consequently, she might cut corners in critical areas like expert witness fees or discovery, quickly settle a few cases to bankroll the rest, or request to dismiss the case. ${ }^{100}$ For example, the plaintiffs' attorneys who initiated the Agent Orange litigation spent millions pursuing the case and eventually exhausted their capital. ${ }^{101}$ Although a new financial group took over the Agent Orange litigation, the same was not true in the New Jersey tobacco litigation. ${ }^{102}$ There, plaintiffs' counsel tried to withdraw, but

94 Id.; Georgene M. Vairo, Reinventing Civil Procedure: Will the New Procedural Regime Help Resolve Mass Torts?, 59 Brook. L. Rev. 1065, 1075 n.47 (1993).

95 See Deborah R. Hensler \& Mark A. Peterson, Understanding Mass Personal Injury Litigation: A Socio-legal Analysis, 59 Brook. L. Rev. 961, 966 (1993).

96 See Harry H. Wellington, Asbestos: The Private Management of a Public Problem, 33 Clev. St. L. Rev. 375, 387-89 (1985). The group was first known as the Asbestos Claims Facility. It was later replaced by a smaller group, the Center for Claims Resolution, which represented twenty-one corporations that manufactured asbestos. See Lawrence Fitzpatrick, The Center for Claims Resolution, 53 Law \& Contemp. Probs. 13, 17 (1990).

97 Amchem Prods., Inc. v. Windsor, 521 U.S. 591, 601 (1997).

98 Id. at 628.

9928 U.S.C. $§ 1715$ (2006) (requiring notice to state and federal officials of proposed class-action settlements and barring final settlement within ninety days of such officials' receipt of notice); FED. R. Civ. P. 23(e), (h) (requiring judges to approve class settlements and permitting them to award attorneys' fees).

100 See Weinstein, supra note 56, at 77 (noting that attorneys might try to dismiss a case that they can no longer afford to pursue).

101 Id. at 62.

102 See id. 
the court refused. ${ }^{103}$ Although courts have this authority in class actions, ${ }^{104}$ no counterpart exists in aggregate litigation.

Even when attorneys can adequately fund the litigation, their cost-sharing agreements can affect strategy. In the New Jersey Vioxx litigation, Judge Carol E. Higbee proposed bifurcating four cases by trying general liability and then specific causation; the plaintiffs' lawyers agreed to split the trial costs four ways. ${ }^{105}$ But when attorney Mark Lanier disagreed with the cases' presentation order and balked at Judge Higbee's proposal to try his case as a stand-alone, he refused to follow through with her plan. In his view, "he had put in more time and money on the Vioxx litigation than any other lawyer in the country-16 weeks in two trials and \$4-5 million": ${ }^{106}$

I'll be quite candid with the Court, I really don't think it is fair at this point for me to go try one single case and have a third one go up on appeal with Merck with another $\$ 2$ million of my money and another six weeks of my time tied up in it. ${ }^{107}$

Thus, litigation financing affects a lawsuit in more ways than one.

4. Astronomical Fees. Attorneys invest in and initiate aggregate litigation to profit from fee awards. This is the private-attorneygeneral model's aim: to encourage private lawyers to initiate civil actions and thereby further the public interest, whether for selfish or altruistic reasons. ${ }^{108}$ But attorneys' fee awards are usually structured so that the counsel's stake far exceeds any one client's recovery, which can tempt lawyers to exploit that dynamic by charging unreasonable fees. To combat this temptation in class actions, Rule 23(h) allows the court to award "'reasonable' attorney fees and nontaxable costs." 109 By contrast, in individual cases, clients "negotiate" and consent to contingent-fee percentages in the attorney's retainer agreement. Without class certification, aggregate litigation could fall prey to the dangers of fee exploitation: A few seasoned lawyers press the defendant into settling and the other plaintiffs' attorneys benefit from those efforts without earning their fees. Although a few judges have invoked

103 Id.

104 Fed. R. Civ. P. 23(g).

105 Prakash, supra note 66, at 30.

106 Id. at 33.

107 Id. (quoting attorney Mark Lauier).

108 See generally Burch, CAFA's Impact, supra note 32, at 2524 ("Because class litigation performs ... semi-public activities, the class action plaintiff's bar has been labeled 'private attorneys general.' "); John C. Coffee, Jr., Rescuing the Private Attorney General: Why the Model of the Lawyer as Bounty Hunter Is Not Working, 42 MD. L. REv. 215, 218 (1983) (discussing the private attorney general model); Harry Kalven, Jr. \& Maurice Rosenfield, The Contemporary Function of the Class Suit, 8 U. CHI. L. REv. 684, 687, 721 (1941) (observing the need for private enforcement to complement government action).

109 FED. R. Civ. P. 23(h). 
their inherent equitable authority and have analogized to class actions and the common-fund doctrine in order to reduce fee awards in multidistrict litigation, ${ }^{110}$ many do not, and the lack of clear authority and guidance for those who do can lead to other inequities. ${ }^{111}$

5. Cram-Down Settlement Practices. Attorneys routinely devise creative settlement provisions that deter class members from opting out and coax them to accept settlements so the lawyers can collect their fees. ${ }^{112}$ Class settlement designers have tried to include: "mostfavored-nation" provisions, which assure those who remain in the settlement that those who opt out will not receive a better deal and, if they do, that the class will also benefit; liens on the defendant's assets in favor of the class, which require those who opt out to wait in line behind class members for years before getting paid; and walk-away provisions, which permit the defendant to withdraw the settlement offer if too many class members opt out. ${ }^{113}$

In the class context, a judge must decide whether these provisions are fair, reasonable, and adequate. ${ }^{114}$ But aggregate litigation lacks not only these judicial safeguards; settlement designers have weakened the one protection claimants still have: the attorney's duty of loyalty. Defendants contract with plaintiffs' law firms (as opposed to with plaintiffs themselves), dub their agreement a "settlement," and require plaintiffs' lawyers to withdraw from representing any client who declines the offer. ${ }^{115}$ The deals essentially use plaintiffs' attor-

110 See, e.g., In re Guidant Corp. Implantable Defibrillators Prods. Liab. Litig., MDL No. 05-1708, 2008 WL 682174, at *19 (D. Minn. Mar. 7, 2008) (capping fee awards at twenty percent, subject to the special master's discretion); In re Vioxx Prods. Liab. Litig., 574 F. Supp. 2d 606, 607 (E.D. La. 2008) (awarding thirty-two percent of the common fund to attorneys); In re Zyprexa Prods. Liab. Litig., 424 F. Supp. 2d 488, 491 (E.D.N.Y. 2006) (capping fees at thirty-five percent of the clients' recovery, subject to the special masters' discretion); Navarro, Terms Met, supra note 76, at A28 (discussing the fee cap set in the Ground Zero litigation).

111 See Silver \& Miller, supra note 41, at 110 (arguing that judicial ability to reduce fees forces lawyers to be overly deferential, inserts unpredictability into contractually bargained for fee awards, and ultimately advantages defendants).

112 See supra Part I.B (discussing quick settlement sell-outs).

113 See, e.g., In re Inter-Op Hip Prosthesis Liab. Litig., 204 F.R.D. 330, 354 (N.D. Ohio 2001) (upholding as fair and reasonable a Rule 23(b)(3) settlement agreement including a most-favored-nation provision as well as a provision that created a lien on defendants' assets); see generally Kathryn E. Spier, The Use of "Most-Favored-Nation" Clauses in Settlement of Litigation, 34 RAND J. ECON. 78, 80 (2003).

114 See Fed. R. Civ. P. 23(e) (instructing courts that a proposed settlement may be approved "only after a hearing and on finding that [it] . . . is fair, reasonable, and adequate").

115 These features figure most prominently in the Vioxx settlement, but contracts between defendants and plaintiffs' law firms extend back to asbestos and Owens Corning's National Settlement Program (NSP). See NAgAREda, supra note 48, at 108-09 (describing the Owens Corning NSP). After some plaintiffs' attorneys contended that the mandatory 
neys' large client inventories as leverage against the clients: If one hundred percent of a lawyer's clients do not agree, then the lawyer's investment in the case is largely unrecoverable.

The Vioxx settlement combined that leverage with an exit clause for Merck. The settlement offer required each participating plaintiffs' attorney to recommend the deal to one hundred percent of her clients and to withdraw from representing those who declined. ${ }^{116}$ Unless eighty-five percent of the claimants consented, Merck could walk away without compensating either the plaintiffs or their attorneys. Plaintiffs who refused the deal and could find alternative representation would continue to litigate before Judge Fallon, who announced his preference for settlement from the beginning and appeared at a press conference to "endorse" the deal. ${ }^{117}$

Similarly, in the Ground Zero workers' case against New York City, settlement designers tried to force plaintiffs to accept the settlement proposal through group cohesion. Attorneys offered a close-knit community of firefighters and police officers $\$ 575$ million if ninetyfive percent of them accepted, but, if one hundred percent agreed, the amount would increase to $\$ 657.5$ million. ${ }^{118}$ In a move that prompted commentators to question the scope of judicial authority in nonclass aggregation, Judge Hellerstein rejected the proposal, dubbed the compensation inadequate, and questioned the large attorneys' fees. ${ }^{119}$ Eventually, attorneys increased the settlement amount to $\$ 625$ million, so long as ninety-five percent approved-95.1\% did. ${ }^{120}$

recommendation and withdrawal settlement provisions in the Vioxx litigation conflicted with ethical rules, the provisions were reinterpreted to mean that attorneys should recommend the deal only if it were in their clients' best interests. Erichson \& Zipursky, supra note 30, at 281; Berenson, supra note 30.

116 Initial Settlement Agreement at 5-6, In re Vioxx Prods. Liab. Litig., MDL No. 01657 (E.D. La. 2007), available at http://www.merck.com/newsroom/vioxx/pdf/Settlement_ Agreement.pdf.

117 See Jef Feeley \& Leslie Snadowsky, Merck Vioxx Judge Threatens To End Suit Consolidation, BLOOMBERG (Jan. 5, 2006), (observing Judge Fallon's preference for settlement from the case's beginning); see also Mark A. Peterson \& Molly Selvin, Mass Justice: The Limited and Unlimited Power of Courts, 54 Law \& Contemp. Probs. 227, 230 (1991) ("Faced with mass tort litigation, judges are not simply neutral arbiters; rather, they have strong personal incentives to speed the judicial process, save costs and labor, and reduce redundancy."); Peter H. Schuck, The Role of Judges in Settling Complex Cases: The Agent Orange Example, 53 U. CHI. L. REv. 337, 361-62 (1986) (arguing that Judge Weinstein in the Agent Orange case was deeply committed to the success of the settlement agreement).

118 See Navarro, Health Costs of 9/11, supra note 31, at A1.

119 See Mireya Navarro, Empathetic Judge in 9/11 Suits Seen by Some as Interfering, N.Y. Times, May 3, 2010, at A17 (questioning the scope of judicial authority in nonclass aggregation).

120 Mireya Navarro, Sept. 11 Workers Agree To Settle Health Lawsuits, N.Y. Times, Nov. 20, 2010, at A1. 
6. Misallocation of Settlement Funds. Once defendants decide to settle, they aim to end the litigation by including as many plaintiffs as possible. But they care little about how settlement funds are distributed among the claimants and their lawyers. ${ }^{121}$ Settlement agreements requiring nearly unanimous consent pressure plaintiffs' attorneys to push their clients to acquiesce so they can collect their fees. Lump-sum settlements, however, where the defendant offers plaintiffs' counsel a sum of money to settle one hundred percent of her cases, tempts some clients to demand a higher payout in return for consenting. ${ }^{122}$

Lump-sum settlements create an ultimatum game: If a claimant (or enough claimants) rejects the settlement, then no one, including the attorney, receives anything. But any attempt to solve this problem by buying off the holdouts would violate the lawyer's ethical obligations to her remaining clients. ${ }^{123}$ The temptation is so great, however, that attorneys may attempt to achieve consensus by hook or by crook, as was the case in the aggregate Kentucky Fen-Phen Settlement where participating attorneys had to provide releases from "each and every" fen-phen client. ${ }^{124}$ Kentucky lawyers William Gallion, Shirley Cunningham, and Melbourne Mills had their staff contact their fen-

121 The infamous Kentucky Fen-Phen Settlement Agreement was one such provision. See Gallion v. Ky. Bar Ass'n, 266 S.W.3d 802, 803-04 (Ky. 2008) (describing the distribution of the fen-phen settlement funds); Erichson, supra note 30, at 985 (noting that the defendant "disavowed any responsibility for allocation of the settlement amount"); see infra notes 124-26 and accompanying text (discussing the fen-phen litigation).

122 See Howard M. Erichson, A Typology of Aggregate Settlements, 80 Notre Dame L. REv. 1769, 1787-91 (2005) (discussing the different lump-sum settlement strategies defendants or defendants' counsel use to settle cases); Charles Silver \& Lynn A. Baker, Mass Lawsuits and the Aggregate Settlement Rule, 32 Wake Forest L. Rev. 733, 767 (1997) (describing the negotiation environment under the unanimous consent requirement as one where there are strong holdout incentives, instead advocating a majority rule); $c f$. Edelman et al., supra note 29, at 99 (noting that because lawyers must pay referral or forwarding fees for some clients, they have an incentive to misallocate in favor of those without fees attached); Bruce L. Hay, The Theory of Fee Regulation in Class Action Settlements, 46 Ам. U. L. REv. 1429, 1472 (1997) (explaining why class counsel might be tempted to settle for a less than optimal amount for their clients). But see Howard M. Erichson, Beyond the Class Action: Lawyer Loyalty and Client Autonomy in Non-class Collective Representation, 2003 U. Chi. Legal F. 519, 573 (noting that though there is an incentive for plaintiffs to demand a higher payoff, this provides the defendant with a powerful incentive to ensure proper allocation of funds to get unanimous consent).

123 Erichson, supra note 30, at 1011.

124 Id. at 985-86 (quoting the Kentucky Fen-Phen Settlement Agreement); see also Gallion, 266 S.W.3d at 803-04. The New York Fen-Phen Settlement by Napoli, Kaiser \& Bern was likewise subject to extensive ethical review and a judge ultimately concluded that "a sufficient showing has been made that the Napoli Firm may have violated the Disciplinary Rules and may have made material misrepresentations in the Letter and the Form of Acceptance." Appel-Hole v. Wyeth-Ayerst Labs. (In re N.Y. Diet Drug Litig.), No. 700000/98, 2007 WL 969426, at *11 (N.Y. Sup. Ct. Mar. 27, 2007). 
phen clients to tell each the amount of their respective settlement awards. But, in violation of Model Rule of Professional Conduct $1.8(\mathrm{~g})$, the lawyers never told their clients the full settlement amount, how much money others would receive, how their settlement amounts were determined, or that they could refuse the settlement and proceed to trial. ${ }^{125}$ They offered their clients less than the total settlement and pocketed the rest-fees well above their contingent-fee arrangement. ${ }^{126}$

Though the practices described sound Grisham-esque, ${ }^{127}$ they are all too real. Consider, for example, Johnson v. Nextel Communications, Inc., where many of the practices just discussed occurred in a single nonclass aggregation. ${ }^{128}$ In Johnson, a group of 587 clients retained a law firm to sue Nextel for employment discrimination. Instead of suing, the law firm allegedly entered into a dispute resolution agreement with Nextel that included kickbacks for the firm. ${ }^{129}$ Nextel would pay the plaintiffs' firm $\$ 2$ million to convince its clients to abandon their legal claims and enter into an expedited mediation or arbitration procedure, an additional $\$ 3.5$ million as clients' claims were resolved, and $\$ 2$ million more to work directly for Nextel—the defendant—as a consultant for two years afterward. ${ }^{130}$ Moreover, if the attorneys could not quickly persuade their clients to accept the settlement, then their fee award would be reduced on a sliding-scale basis: the longer it took to achieve their clients' consent, the less their fee award. ${ }^{131}$ Without the consent of all 587 clients, neither the clients nor the lawyers would have a right to receive anything. ${ }^{132}$ According to the Second Circuit, by entering into this agreement with the defendant, the plaintiffs' law firm "violated its duty to advise and represent each client individually, giving due consideration to differing claims, differing strength of those claims, and differing interests in one or more proper tribunals in which to assert those claims." 133

125 Gallion, 266 S.W.3d at 803-04. See Model Rules of Prof'l Conduct R. 1.8(g) (2010) (requiring attorneys to inform clients involved in an aggregate settlement about not only their settlement amount, but the amount that everyone else involved in the settlement receives).

126 Erichson, supra note 30, at 986.

127 For example, Wally Figg's antics, which included making false advertisement claims for legal services, come readily to mind. John Grisham, The Litigators 2-3 (2011).

128660 F.3d 131 (2d Cir. 2011).

129 Id. at 134-35.

$130 \mathrm{Id}$.

131 Id. at 139.

132 Id. at 140.

133 Id. 
Although Rule 23's effectiveness in fashioning a judicial surrogate to protect absent class members is open to debate, ${ }^{134}$ when that protective layer disappears altogether-as it does in nonclass aggregation-the problems metastasize. The agency problems remain, but the judge no longer has clear authority to get involved and counsel's ethical obligations to the group are muddied by traditional ethical rules that assume individual client monitoring. ${ }^{135}$ Just as in class actions, plaintiffs' attorneys in nonclass aggregation face enormous pressure to tender finality to the defendant: That is, after all, what ultimately dictates the lawsuit's success. But the quest to achieve that finality outside the well-traveled class-action path spurs unethical behavior. And tying the lawyer's payday to the settlement-as the contingent fee does-only adds fuel to this fire. In short, this shift toward nonclass aggregation presents a striking need for someone, somehow, to monitor the litigation and the attorneys on the plaintiffs' behalf.

\section{Alternative Litigation Financing}

The agency problems in aggregate litigation, the increased need for nontraditional funding sources, and the lack of a viable monitor portend a number of troublesome tradeoffs. In a near-perfect world, ${ }^{136}$ each individual would be able to pursue the full value of her claim-no matter how small—and perhaps even avoid the transaction costs associated with attorneys' fees. The plaintiff would be eminently rational, swayed neither by the shrewd framing of settlement options, by the press of mortgage payments or medical bills, nor by inexperience or informational asymmetries. ${ }^{137}$ But this is not the world we live in. Rather, our world is one in which judges refuse to certify class actions and drive the potentially wayward agent to either abandon the

134 See, e.g., William B. Rubenstein, The Fairness Hearing: Adversarial and Regulatory Approaches, 53 UCLA L. REv. 1435, 1445 (2006) (observing that judges "suffer from a remarkable informational deficit in the fairness-hearing process"); Adam S. Zimmerman \& David M. Jaros, The Criminal Class Action, 159 U. PA. L. Rev. 1385, 1429-30 (2011) (observing that "[c]ommentators have questioned the effectiveness of judicial review in class action settlements," but also noting that courts can demand that parties "explain the complex trade-offs they have made in arriving at a settlement, and require a reasonable decision-making process when they arrive at a distribution that affects restitution to thousands of potential victims").

135 See Johnson, 660 F.3d at 140 ("First, because [the plaintiffs' firm] was not lead counsel in a class action, the class-protective provisions of [Rule 23] were not triggered.").

136 Obviously, in a perfect world, torts would not occur and people would honor their contractual obligations without having to turn to the legal system for recourse.

137 See generally Adam S. Zimmerman, Funding Irrationality, 59 Duke L.J. 1105, 1109-11 (2010) (describing the cognitive biases that affect plaintiffs' settlement decisions in large-scale litigation). 
endeavor altogether or to recruit and represent hundreds of roughly similarly situated clients with little potential for establishing a meaningful attorney-client relationship.

Given this state of affairs, plaintiffs' attorneys may increasingly look to third-party financing to turn nonclass aggregation into a winning economic proposition. But this solution includes tradeoffs: the financiers hoping to turn a profit off of others' misfortune versus the palpable need for continued access to the lawyers, to the courthouse, and to justice; the questions about decisional control that pit paternalism against autonomy; and the ethical concerns raised when someone other than the client has a say in the litigation versus the dire need for attorney oversight. And these tradeoffs are but the tip of the iceberg. Underlying each is a host of issues that range from the practical-whether clients can give informed consent to allow financiers to share in their proceeds- to the convoluted, such as the myriad, mixed incentives that result when a new entity enters into the already complex principal-agent dynamic explored above. Further still, these knotty questions say nothing about what will become of cases in which clients principally want declaratory or injunctive relief-cases that third-party financiers have no incentive to fund. This Part begins to untangle these issues by exploring the types of alternative litigation financing presently available and tracing the incentives of financiers, plaintiffs, and plaintiffs' lawyers. Part III then considers whether third-party financing might help alleviate the agency problems that arise in aggregate litigation by shouldering litigation costs and providing a much needed monitor.

\section{A. A Taxonomy of Third-Party Financing}

Presently, there are three main types of third-party financing: consumer legal funding, loans to plaintiffs' law firms, and commercial dispute funding - each of which raises distinct legal and ethical concerns. Third-party funding, or "alternative litigation financing," began in Australia, made its way to the United Kingdom, and took root in the United States when companies started loaning money to cashstrapped plaintiffs who could not use their lawsuit as bank collateral, but needed money for day-to-day expenses. ${ }^{138}$ This form of thirdparty financing, known as consumer legal funding, is a nonrecourse

138 Nate Raymond, More Attorneys Exploring Third-Party Litigation Funding, LAw.com (June 4, 2010), http://www.law.com/jsp/article.jsp?id=1202459195060\&slreturn=1 (describing how third-party litigation migrated from Australia, to the United Kingdom, and then to the United States). Australia does not allow contingency fees, but roughly five investment firms fill the void. Susan Lorde Martin, Litigation Financing: Another Subprime Industry That Has a Place in the United States Market, 53 Vill. L. Rev. 83, 107 (2008). 
loan, meaning that a litigant would not need to pay back any more than what she receives from the lawsuit. The plaintiff is not personally liable-if she loses the suit, the lender loses the money. ${ }^{139}$ Given the risk involved, interest rates can be quite high-between thirty-six and one hundred and fifty percent per year-but the nonrecourse basis enables funders to avoid state usury laws. ${ }^{140}$ Consumer legal funders making cash advances to plaintiffs traditionally run up against historical maintenance doctrines, which prohibit third parties from assisting a litigant in pursuing a lawsuit. ${ }^{141}$

Over time, a second type of financing emerged: Loaning money to plaintiffs' law firms, as opposed to cash-advance loans to plaintiffs themselves, is a growing market within a niche practice. As of early 2010 , only around nine companies provided loans to law firms, but as of late 2011, that number had grown to around twelve. ${ }^{142}$ When financiers lend money to law firms, they secure those debts not by a single case, but by all of the firm's assets, including future fee awards from other cases. Occasionally, funders will lend lawyers money based on a trial verdict on appeal. ${ }^{143}$ Unlike a nonrecourse loan, plaintiffs' firms must repay the money regardless of whether they win or lose a partic-

139 Steven Garber, Rand Corp., Alternative Litigation Financing in the United States: Issues, Knowns, And Unknowns 9, 10 (2010); see also What Is Legal Finance and Who Does It Help?, Am. Legal Fin. Assoc., http://www.americanlegalfin. com/alfa1/LinkClick.aspx?fileticket $=1 \mathrm{Ia} 9 \mathrm{qsxV} 0 \mathrm{eQ} \% 3 \mathrm{~d} \& \mathrm{tabid}=71 \& \mathrm{mid}=553$ (last visited Sept. 5, 2012) (explaining that member organizations fully accept the risk of cases being won or lost and will not recover if the client does not recover).

140 Kirby Griffis, Follow the Money: Litigation Funders Back Your Foes, Metropolitan Corp. Couns., July 2011, at 1.

141 E.g., Osprey, Inc. v. Cabana Ltd. P'ship, 532 S.E.2d 269, 273 (S.C. 2000). For more information on changes to current state laws, see Part III.D.1.

142 Steven Garber identified nine companies that loaned money to plaintiffs' law firms in early 2010: Advanced Legal Capital; Advocate Capital, Inc.; Counsel Financial; Evergreen Funding Group; LawFinance Group, Inc.; Oxbridge Financial Group LLC; Rapid Funds; RD Legal Capital; and ViaLegal Funding. GARBER, supra note 139, at 14. Several other companies now exist, including Amicus Capital Services, LLC, BridgePoint Financial Services, and LawsuitLoanHQ. See Disbursement Financing, BRIDGePoint Fin. SERvs. InC., http://www.bpfin.com/disbursementfinancing (last visited Sept. 5, 2012) ("[We] recognize[] that personal injury law firms are capital intensive businesses with unique cash-flow cycles relative to other professional service providers."); Law Firm Loans, Amicus CAPITAL SERvs., http://www.amicuscapitalservices.com/law-firmloans.html (last visited Sept. 5, 2012) ("We offer loans secured by your portfolio of cases, for four to five times more money than a traditional bank could offer."); Litigation Financing, LAwsuitLoAnHQ, http://lawsuitloanhq.com/plaintiff-case-costs.htm (last visited Sept. 5, 2012) ("We are experts in legal finance, lawsuit loans, law firm cash-flow financing, attorney funding, law firm loans and legal practice line of credit.").

143 Alison Frankel, Helping Underfunded Plaintiffs Lawyers-At a Price, LAw.com (Feb. 13, 2006), http://www.law.com/jsp/law/international/LawArticleFriendlyIntl.jsp?id= 900005547685 . 
ular case. ${ }^{144}$ Such was the case in the Ground Zero workers' litigation: Napoli Bern had to reimburse Counsel Financial regardless of the case's outcome. ${ }^{145}$ Interest rates are significantly higher than what a bank might charge for a loan based on traditional assets-rates tend to be "north of 20 percent," making these loans unattractive to wellfinanced firms. ${ }^{146}$ Still, lenders in this area fill a need that banks do not: Banks loan money based on traditional assets and collateral, not on potential winnings. ${ }^{147}$

Finally, a burgeoning market of around seven lenders provides money directly to businesses to finance commercial, business-versusbusiness disputes in exchange for either a percentage of the plaintiff's eventual recovery or a multiple of the supplied capital. ${ }^{148}$ Those percentages range from thirty-five to sixty-seven percent of the lawsuit's recovery. ${ }^{149}$ This kind of lending may run into historical prohibitions on champerty, a form of maintenance where the lender receives an interest in the suit's outcome. ${ }^{150}$ Two of the lenders in this area, Juridica Investments and Burford Capital, Ltd., are publicly traded companies in the Alternative Investment Market on the London Stock Exchange. They principally bankroll international arbitrations, intellectual property, breach of contract, and antitrust disputes. ${ }^{151}$

144 GARBER, supra note 139, at 9-10.

145 Goldstein \& Edelman, supra note 14.

146 Frankel, supra note 143.

147 As LawFinance prominently explains in its slogan, "We Do What Banks Won't," LAwFInANCE GRP., http://www.lawfinance.com/ (last visited Sept. 5, 2012).

148 See GARBER, supra note 139, at 13-15 (noting such lenders as ARCA Capital, Burford Capital, Calunius Capital, IMF, Juridica Investments, and Juris Capital); Hamerman, supra note 62, at 17 (noting that Juridica's clients are primarily Fortune 500 companies, large universities, and law firms); Vanessa O'Connell, Funds Spring Up To Invest in High-Stakes Litigation, WALL ST. J., Oct. 3, 2011, at B1 ("At least three start-up business are entering the fledgling 'alternative litigation funding' market this year, creating funds that will invest at least a few million dollars in a case in exchange for a share of the lawsuit's winnings, which can be in the several-million-dollar or even billion-dollar range."); BlackRobe CAPital, http://www.blackrobecapital.com (last visited Sept. 5, 2012) (noting that BlackRobe Capital was founded, in part, by Tim Scrantom, who also began Juridica).

149 Raymond, supra note 138.

150 See Osprey, Inc. v. Cabana Ltd. P'ship, 532 S.E.2d 269, 273 (S.C. 2000) ("[P]ut simply, maintenance is helping another prosecute a suit; champerty is maintaining a suit in return for a financial interest in the outcome; and barratry is a continuing practice of maintenance or champerty." (quoting In re Primus, 436 U.S. 412, 424 n.15 (1978))). For more information on current changes to states' champerty laws, see Part III.D.1.

151 See GARBER, supra note 139, at 13; Hamerman, supra note 62; Raymond, supra note 138; Submission from Burford Grp. LLC, Paper Concerning Alternative Litigation Financing 2 (Feb. 15, 2011), available at http://www.americanbar.org/content/dam/aba/ migrated/2011_build/ethics_2020/comments_on_alternative_litigation_financing_issues_ paper.authcheckdam.pdf ("Burford Group carries on its activities in the United States through its subsidiary, Burford Group LLC."). 
Most commercial dispute lenders currently steer clear of funding aggregate litigation and leave those investments to funders who loan money to plaintiffs' law firms. But, as the following sections explore, this model of contracting with the plaintiffs for a portion of their proceeds has the most potential for creating a workable monitor in large scale, multidistrict litigations. ${ }^{152}$ And for those investors or commercial dispute lenders seeking a longer-term investment with a potentially exponential payoff, funding aggregate litigation is their logical next step.

\section{B. Mixed Litigation and Investment Incentives}

Finding a viable intermediary entails paying careful attention to financiers' incentives and the ways in which those incentives dovetail with plaintiffs' aims and public-enforcement goals. These interests hinge on litigation's two primary functions: (1) resolving disputes and (2) preventing disputes by defining, shaping, and clarifying the law to make behavioral modification and compliance possible. ${ }^{153}$ Preventing disputes relies on litigants to push, shape, and define legal ambiguities through arguments and establishing precedent. Yet, there may be a conflict between dispute-resolution goals and deterrence aims: If a settlement offer is generous enough to buy a plaintiff off, she has little incentive not to accept it and push for further judicial rulings and appeals. ${ }^{154}$ Repeat players, however, like nonprofit groups, attorneys, funders, and defendants, have at least some impetus to invest in setting precedent and clarifying laws. ${ }^{155}$ Although funders are repeat players, many would prefer a quick settlement and an expeditious investment return.

The following sections analyzes the incentives and biases of plaintiffs' attorneys, the plaintiffs themselves, and third-party financiers. Part III then considers how mixing these incentives by allowing financiers to fund aggregate litigation could change and distort them. Note

152 In fact, Burford Capital, Ltd. is currently funding the Ecuadorian personal injury litigation against Chevron, which involves thousands of plaintiffs. Hurley, supra note 15. James Tyrrell, Jr., the Ecuadorian plaintiffs' attorney, also acts as outside counsel to both Burford and Juridica. Raymond, supra note 138.

153 See generally Robert G. Bone, Lon Fuller's Theory of Adjudication and the False Dichotomy Between Dispute Resolution and Public Law Models of Litigation, 75 B.U. L. REv. 1273, 1279-82 (1995) (discussing litigation's dual functions).

154 See David Luban, Settlements and the Erosion of the Public Realm, 83 Geo. L.J. 2619, 2623 (1995) (noting that private parties often have an inadequate incentive to create precedent); Richard H. McAdams, The Expressive Power of Adjudication, 2005 U. ILL. L. REV. 1043, 1114 (observing that disputants have "insufficient incentive to care about the precedential effect on future disputes in which they are not participants").

155 Kritzer, supra note 78, at 16; Maya Steinitz, Whose Claim Is This Anyway? ThirdParty Litigation Funding, 95 MinN. L. Rev. 1268, 1312-18 (2011). 
too that special ethical issues may arise on the very rare occasion when the plaintiffs' attorney is also an investor in or affiliated with the third-party funder. ${ }^{156}$

\section{Plaintiffs' Attorneys' Incentives}

Plaintiffs' attorneys, like the plaintiffs themselves, are vulnerable to decision-making biases. The principal-agent literature explored in Part I.B exposes the basic economic problem and discusses attorneys' financial interests, but only partially explains attorneys' incentives and bias toward self-interest. Although lawyers are less subject to contrast biases and emotional tugs than plaintiffs are, ${ }^{157}$ they are not always solely motivated by financial calculations. As repeat players, attorneys' reputations among the plaintiffs' bar, defense attorneys, and clients are important for obtaining referrals, maintaining credible threats, encouraging repeat business, and achieving favorable settlements. ${ }^{158}$ An attorney's reputation may thus function as an economic control on potential self-dealing and collusive or quick-pay settlements. ${ }^{159}$ Likewise, settlement quality is heavily intertwined with the lawyer's reputation and her ability to pose a plausible threat to defendants through accepting meritorious cases, having the resources available for case preparation and trial, and making justifiable settlement demands. ${ }^{160}$

Having the resources to win favorable settlements and craft a reputation as a serious attorney who provides those results is far more difficult in the current economic climate. ${ }^{161}$ Consequently, plaintiffs' attorneys are more likely to turn to nontraditional funding sources for four reasons.

First, recall that the fixed costs of aggregate litigation, as opposed to a class action, are likely to increase substantially. ${ }^{162}$ Not only must lawyers spend the same limited resources on developing generic assets like scientific research and expert analysis, they must also pour money

156 For some guidance on these issues, see ABA Comm'n on ETHics 20/20, White Paper on Alternative Litigation Finance 17-20 (2011) (draft), available at http:// www.americanbar.org/content/dam/aba/administrative/ethics_2020/20111019_draft_alf_ white_paper_posting.authcheckdam.pdf; and Model Rules of Prof'L Conduct R. 1.7(a)(2), 1.8(e), 1.8(i) (2010).

157 See infra Part II.B.2 (discussing plaintiffs' contrast bias).

158 KRITZER, supra note 78, at 232-39.

159 Id. at 221-22; Korobkin \& Guthrie, Psychology, supra note 8, at 123.

160 KRITZER, supra note 78, at 242.

161 See Alexa Hyland, Firms Make Case for Legal Loans: Companies See Profit in Funding Contingency Suits, L.A. Bus. J., Apr. 21, 2008, available at 2008 WL 25525068 (noting that it is more difficult to obtain traditional financing from banks).

162 See supra Part I.A. 
into advertising, client recruitment, client counseling, filing fees, and the administrative costs of keeping up with each client's documents.

Second, because plaintiffs' attorneys must either work on a contingent-fee basis or prevail before the judge awards them fees under a fee-shifting statute, they frequently encounter cash-flow problems. These problems can bring them close to insolvency and impact their ability to accept new cases, invest sufficient resources in current cases, and compete with more established law firms. ${ }^{163}$ Cash-flow problems likewise undermine attorneys' ability to pose a credible threat to the defendant, which usually has far more resources than the plaintiffs and can leverage its superior economic position in hopes of pressuring plaintiffs to accept a low-ball offer. ${ }^{164}$

Third, the economic downturn and tightened lending standards have all but dried up traditional funding sources like banks, ${ }^{165}$ which drive the ever-entrepreneurial and creative lawyer to seek nontraditional funding. Finally, even the financially solvent firm might seek alternative funding to fortify its threat to the defendant. Because funders conduct their own due diligence to assess the case's merits, if funding is disclosed, it sends both parties an additional signal about the value of plaintiffs' claims. ${ }^{166}$

\section{Plaintiffs' Incentives}

Nonclass aggregation adds a new wrinkle in evaluating plaintiffs' litigation aims. In class actions, dealing with plaintiffs who are largely absent and typically disinterested is a much simpler proposition than managing hundreds or thousands of clients whose individual goals do not always align with each others' or their attorneys'. ${ }^{167}$ Plaintiffs' motivations and incentives for litigating do not fit easily within a single box. Consider a few examples: A woman paralyzed in a rollover

163 GARBER, supra note 139, at 23.

164 See generally NAGAREDA, supra note 48, at 14-15 (discussing the need for ample funds for plaintiffs to create a credible threat to defendants).

165 Hyland, supra note 161.

166 See GARBER, supra note 139, at 24, 32-33 (observing that "a defendant who knows that the plaintiff has ALF may infer ... that the legal claim has legal merit or high economic value"); Telis Demos, Cashing In on Litigation, Fortune, May 4, 2009 (noting that shares had gone up twenty percent since the launch of a lawsuit by a hedge fund supported by Juridica); Max Schanzenbach \& David Dana, How Would Third Party Financing Change the Face of American Tort Litigation? The Role of Agency Costs in the AttorneyClient Relationship 12 (Sept. 14, 2009), available at http://www.law.northwestern.edu/ searlecenter/papers/Schanzenbach_Agency\%20Costs.pdf. As Garber suggests, this is far from a straightforward proposition and it raises substantial questions for game theorists. GARBER, supra note 139, at 33 n.29.

167 For more information on why plaintiffs in aggregate litigation might be more or less interested, see Burch, Litigating Together, supra note 87, at 99-100. 
accident demanded that Ford and Firestone broadcast a videotaped apology before she would settle; Paula Jones demanded (but never received) an apology from President Clinton; and many of the September 11 victims wanted information about the facts and circumstances, to hold those responsible accountable, to publicly condemn wrongdoing, and to take action that would promote change. ${ }^{168}$

When asked why they litigated, many plaintiffs with tort claims such as medical injuries insisted that they were litigating on principle, not for the money. ${ }^{169}$ Plaintiffs litigate to establish precedent, express their feelings, have the defendant admit fault and responsibility, ensure that the event will never happen again, reveal cover-ups, discover answers, punish or gain retribution, receive an apology, obtain dignity and respect post-injury, and be heard. ${ }^{170}$ Consequently, as Part III.E explores, financially motivated third-party financiers may not be the right solution for all plaintiffs, though plaintiffs' attorneys working on a contingency fee have long monetized all of these claims.

Plaintiffs may not act rationally when deciding whether and under what terms to settle. In making settlement decisions, plaintiffs may fall prey to (1) contrast bias, (2) tendencies toward risk aversion, and (3) group decision-making biases, such as confirmation bias and group polarization.

First, contrast bias affects the way that plaintiffs evaluate settlement options depending on what other options are offered to them

168 See Erin Ann O’Hara \& Douglas Yarn, On Apology and Consilience, 77 WAsh. L. REV. 1121, 1125 (2002) (discussing the apology demanded by the paralyzed women and Paula Jones); Gillian K. Hadfield, Framing the Choice Between Cash and the Courthouse: Experiences with the 9/11 Victim Compensation Fund, 42 Law \& Soc'y Rev. 645, 649 (2008) (discussing the September 11 victims' thoughts on litigation).

169 See Tamara Relis, "It's Not About the Money!": A Theory of Misconceptions of Plaintiffs' Litigation Aims, 68 U. PitT. L. Rev. 341, 378-79 (2007).

170 Id. at 361-63 \& fig.4. Other studies confirm these results. E.g., Randall P. Bezanson, The Libel Suit in Retrospect: What Plaintiffs Want and What Plaintiffs Get, 74 Calif. L. Rev. 789, 799-800 (1986); Marc Galanter, Adjudication, Litigation, and Related Phenomena, in Law AND the Social Sciences 151, 191-92 (Leon Lipson \& Stanton Wheeler eds., 1986); Marc Galanter, Reading the Landscape of Disputes: What We Know and Don't Know (and Think We Know) About Our Allegedly Contentious and Litigious Society, 31 UCLA L. Rev. 4, 30-31 (1983); Deborah R. Hensler, Resolving Mass Toxic Torts: Myths and Realities, 1989 U. ILL. L. Rev. 89, 99 \& tbl.6; E. Allan Lind et al., In the Eye of the Beholder: Tort Litigants' Evaluations of Their Experiences in the Civil Justice System, 24 Law \& Soc'y Rev. 953, 965-67 (1990); Sally Engle Merry \& Susan S. Silbey, What Do Plaintiffs Want? Reexamining the Concept of Dispute, 9 Just. Sys. J. 151, 153 (1984); O'Hara \& Yarn, supra note 168, at 1125; Tom R. Tyler, A Psychological Perspective on the Settlement of Mass Tort Claims, 53 Law \& Contemp. Probs. 199, 204 (1990). But see Richard Lempert \& Joseph Sanders, An Invitation to Law and Social SCIENCE 175 (1986) (concluding that plaintiffs other than those involved in discrimination lawsuits are principally concerned about economic well-being). 
simultaneously and how many choices they have. ${ }^{171}$ For instance, people tend to decide more quickly if a settlement offer includes only a single option as opposed to an offer containing two attractive choices, regardless of whether both options leave the decision maker better off. Additionally, including a third, inferior option makes an already available choice appear even more attractive than it otherwise would. ${ }^{172}$ Although frank legal advice diminishes this bias, ${ }^{173}$ the circumstances of large-scale aggregation make candid, complete advice unlikely. ${ }^{174}$ Aggregated clients have attenuated relationships with their attorneys and lawyers' self-interest as financiers may color their substantive advice. ${ }^{175}$

Second, risk preferences may affect plaintiffs' decision making in ways that differ from the risk preferences of their attorneys or thirdparty financiers. Research shows that cognitive psychological factors like framing, ${ }^{176}$ anchoring (based on initial settlement offers), and equity seeking 177 affect plaintiffs' risk preferences more so than they

171 For examples of studies demonstrating the existence of contrast bias, see Mark Kelman et al., Context-Dependent in Legal Decision Making, 25 J. Legal Stud. 287, $297-$ 300 (1996); Russell Korobkin \& Chris Guthrie, Psychological Barriers to Litigation Settlement: An Experimental Approach, 9 Мich. L. Rev. 107, 129-42 (1994) [hereinafter Korobkin \& Guthrie, Psychological Barriers]; and Zimmerman, supra note 137, at 1142-49.

172 For demonstrations of contrast bias and framing effects, see DAN ARIELY, Predictably Irrational: The Hidden Forces That Shape Our Decisions 8-10 (2008); Chris Guthrie, Panacea or Pandora's Box?: The Costs of Options in Negotiation, 88 Iowa L. Rev. 601, 619 (2003); Zimmerman, supra note 137, at 1143-45; see also Ravi Dhar, Consumer Preference for a No-Choice Option, 24 J. Consumer Res. 215, 229 (1997); Joel Huber, John W. Payne \& Christopher Puto, Adding Asymmetrically Dominated Alternatives: Violations of Regularity and the Similarity Hypothesis, 9 J. Consumer Res. 90, 94 (1982); Sanjay Mishra, U.N. Umesh \& Donald E. Stem, Jr., Antecedents of the Attraction Effect: An Information-Processing Approach, 30 J. Marketing Res. 331, 332-35 (1993); Simone Moran \& Joachim Meyer, Using Context Effects To Increase a Leader's Advantage: What Set of Alternatives Should Be Included in the Comparison Set?, 23 Int'l J. Res. Marketing 141 (2006); Eldar Shafir, Itamar Simonson \& Amos Tversky, Reason-Based Choice, in Choices, Values, and Frames 607-08 (Daniel Kahneman \& Amos Tversky eds., 2000).

173 See Korobkin \& Guthrie, Psychology, supra note 8, at 82 (noting how lawyers have the ability to persuade clients to settle); Zimmerman, supra note 137, at 1146 (noting that legal advice can reduce biases).

174 See supra Part I.B.

175 Zimmerman, supra note 137, at 1146 n.186; see generally Korobkin \& Guthrie, Psychology, supra note 8, at 124.

176 See Korobkin \& Guthrie, Psychological Barriers, supra note 171, at 109, 129-31 ("People avoid risk when they choose between options they understand as gains, but they prefer risk when they select between choices viewed as losses.").

177 See id. at 109 ("People want what they are legally entitled to, but they also want recognition of their claim's validity."). 
do their attorneys'. ${ }^{178}$ In contrast, their attorneys' desire to settle is likely animated principally by financial calculations. ${ }^{179}$ Because trial is particularly expensive for a contingent-fee lawyer, she is likely to favor settlement more often than her clients, who may be more affected by contrast bias, anchoring, or nonmonetary motivations. ${ }^{180}$ Disparate risk preferences also mean that settlements may not reflect the merits so much as the plaintiff's (or her attorney's) risk tolerance. ${ }^{181}$ This can result in suboptimal deterrence for defendants who take calculated financial risks, thereby undermining one of litigation's public functions.

Risk preferences are likewise affected by how much money is at stake compared to a person's overall wealth: People tend to be more willing risk takers when less money is in play. ${ }^{182}$ This so-called "peanuts effect," where people take risks when playing for "peanuts," suggests that interested parties with less at stake will be less risk averse when litigating. ${ }^{183}$ So, in a negative-value case like a consumer suit, the contingent-fee lawyer with a substantial stake in the whole litigation is likely more risk averse than her clients. But, when the stakes are higher-as in personal injury or product liability cases-risk preferences may align between the lawyer and the client. A middle-class plaintiff with a claim worth a few hundred thousand dollars, a contingent-fee attorney, and even a third-party financier with a substantial investment in the case's outcome may all be similarly risk averse. But a plaintiff who litigates for nonmonetary reasons, like revealing coverups or wanting to punish the defendant, may have a higher risk toler-

178 See Korobkin \& Guthrie, Psychology, supra note 8, at 124 (finding that attorneys evaluate litigation choices differently from their clients); Korobkin \& Guthrie, Psychological Barriers, supra note 171, at 111 (same).

179 See Korobkin \& Guthrie, Psychology, supra note 8, at 124 (predicting that financial considerations are more likely to influence lawyers than litigants in making settlement decisions).

180 See id. at 122-23 (discussing the effect of contingent-fee arrangements on lawyers' incentives to settle).

181 See Molot, supra note 18, at 70 (describing how differences in the parties' risk preferences may influence their attitudes toward settlement).

182 See Harry Markowitz, The Utility of Wealth, 60 J. PoL. ECON. 151, 151-52 (1952) (describing a hypothesis that links a person's level of wealth with his risk preferences); Drazen Prelec \& George Lowenstein, Decision Making over Time and Under Uncertainty: A Common Approach, 37 Mgmt. ScI. 770, 774 (1991) (explaining how the magnitude of a choice's outcome influences a person's risk preferences); Bethany J. Weber \& Gretchen B. Chapman, Playing for Peanuts: Why Is Risk Seeking More Common for Low-Stakes Gambles?, 97 Org. Behav. \& Hum. Decision Processes 31, 31-33 (2005) (discussing how risk preferences vary depending on the amount of money at stake).

183 Michael Gousgounis, Association-Driven Aggregate Litigation: Peanuts Effect and Democratization of Litigation Governance 5 (May 1, 2009) (unpublished manuscript), available at $\mathrm{http}: / /$ papers.ssrn.com/sol3/papers.cfm?abstract_id=1469046. 
ance. The same might be true for a lawyer for whom a particular lawsuit is as much about creating or maintaining a certain reputation (say, for large settlements or jury awards) as it is about a specific fee. ${ }^{184}$

Third, the risk-seeking versus risk-avoiding dynamic changes further when decision making is no longer an individual endeavor, but requires group consensus-as is frequently the case in aggregate litigation. As I have explored in the past, interpersonal group dynamics require heightened sensitivity to the decision-making process as part and parcel of litigation procedures. ${ }^{185}$ As plaintiffs participate and deliberate in group governance, they tend to influence one another's decisions, for better or worse. If group norms stifle dissent among homogenous group members, then members' convictions can make them discount contrary evidence (confirmation bias) or move toward extreme positions (group polarization). ${ }^{186}$ Cohesive groups, however, might incur moral obligations of solidarity and loyalty to one another, which means that they may ultimately push for a settlement that is in the best interests of the group as a whole. ${ }^{187}$ So long as the cohesive group incorporates diverse viewpoints (such as those of their attorneys, other plaintiff groups, or a third-party financier) into their dis-

184 See KRITZER, supra note 78, at 219-22 (discussing the importance of reputation for contingent-fee lawyers).

185 See, e.g., Burch, Litigating Together, supra note 87; Elizabeth Chamblee Burch, Group Consensus, Individual Consent, 79 Geo. Wash. L. Rev. 506 (2010) [hereinafter Burch, Group Consensus]; Elizabeth Chamblee Burch, Litigating Groups, 61 Ala. L. Rev. 1 (2009). I do not mean that litigation is truncated in terms of time to settlement, but that aggregate litigation lacks the traditional progression toward trial that an individual litigant might experience.

186 Elizabeth Chamblee Burch, Optimal Lead Plaintiffs, 64 VAND. L. REv. 1109, 1152-54 (2011); Stefan Schulz-Hardt et al., Biased Information Search in Group Decision Making, 78 J. Personality \& Soc. Psychol. 655, 656-59 (2000); see also Dieter Frey, Recent Research on Selective Exposure to Information, in 19 AdvANCES IN EXPERIMENTAL Social Psychology 41, 52-53 (Leonard Berkowitz ed., 1986) (describing studies showing that people prefer information that is consonant with their own attitudes); Joshua Klayman, Varieties of Confirmation Bias, in Decision Making from a Cognitive Perspective 385, 385-87, 398 (Jerome Busemeyer, Reid Hastie \& Douglas L. Medin, eds. 1995) (discussing several kinds of confirmation biases, and the connection between evidence interpretation and bias); Raymond S. Nickerson, Confirmation Bias: A Ubiquitous Phenomenon in Many Guises, 2 Rev. Gen. Psychol. 175, 178, 210 (1998) (summarizing studies indicating that people give greater weight to evidence supporting their beliefs, and discussing how confirmation biases may compound the effects of making inadequately informed decisions).

187 See Burch, Group Consensus, supra note 185, at 519-23 (describing how solidarity and loyalty may develop among a group of plaintiffs, and how those notions may affect the group's dynamics). 
cussion and decision-making processes, they can avoid group decisionmaking's most detrimental effects. ${ }^{188}$

\section{Financiers' Incentives}

Financiers' investment incentives are relatively simple: They want to make money and are willing to take significant risks for significant returns, at least so long as they do not exhaust their capital along the way. ${ }^{189}$ That simple incentive, however, belies the complexity that animates it. Take settlement, for example: Commercial-claims lenders tend to invest in lawsuits that may settle quickly so they can collect their share and move on to other ventures. But funders who loan money to plaintiffs' law firms or to plaintiffs themselves based on hefty annual interest rates may want to delay settlement to increase those charges. ${ }^{190}$ And no lender is concerned with equitable or injunctive relief.

Incentives vary depending on the investment and the investment strategy. For example, financiers backing commercial, businessdispute claims will have incentives that differ from those who loan money to plaintiffs' law firms. When investors bankroll commercial, business-versus-business claims in exchange for a share of the eventual recovery, they tend to avoid cases that involve novel legal questions or that could end up in a jury trial. ${ }^{191}$ Juries inject too much

188 See Burch, Litigating Together, supra note 87, at 117-23 (discussing the use of special officers and the encouragement of communication among plaintiffs as methods of promoting cooperation).

189 See GARBER, supra note 139, at 24 (explaining the costs that alternative litigation financing companies face and the risks they are willing to accept).

190 See generally Terry Carter, Cash Up Front: New Funding Sources Ease Financial Strains on Plaintiffs Lawyers, ABA Journal (Oct. 8, 2004, 1:31 AM), http:// www.abajournal.com/magazine/article/cash_up_front ("[C]ash advances go to plaintiffs before trial or settlement, with monthly interest rates ranging from 2 percent to 4 percent in some states to . . . as high as 15 percent in Nevada. These rates sometimes are compounded and can approach 200 percent annually."); Ben Hallman, Influential N.Y. Ethics Panel Cautions Lawyers on Dealing with Lawsuit Funding Companies, CTr. For PuB. INTEGRITY (June 16, 2011, 5:38 PM), http://www.iwatchnews.org/2011/06/16/4935/impactinfluential-ny-ethics-panel-cautions-lawyers-dealings-lawsuit-funding. But see William J. Gorta, Bitten by Lawsuit 'Sharks,' N.Y. Post, Dec. 12, 2011, http://www.nypost.com/p/ news/local/brooklyn/bitten_by_lawsuit_sharks_50H1EYevFanwCmIFBzgsWM (describing a $\$ 4000$ loan that morphed into $\$ 116,000$ with interest and fees; before settlement, the judge threatened to rule that the practice was usurious and unconscionable). As the preceding citation shows, even consumer funders might prefer to receive a quick turnaround on their investment.

191 See Jonathan D. Glater, Investing in a Portfolio of Lawsuits, for a Share of the Awards, N.Y. Times, June 3, 2009, at B1 (interviewing Richard Fields, the CEO of Juridica Capital Management, who describes how Juridica selects cases). Both Juridica and Burford Capital, Ltd. invest in commercial disputes. See Raymond, supra note 138. 
uncertainty into the process, as do politically charged cases. ${ }^{192}$ For similar reasons, these investors avoid cases likely to be appealed or where the opposing party lacks deep pockets. ${ }^{193}$

Richard Fields, the CEO of Juridica Capital Management, a company that trades on the London Stock Exchange but invests mostly in commercial claims within the United States, explained that his company funded only seventeen out of 122 potential cases last year. ${ }^{194}$ Selecting cases involved a "two-month due diligence process that examine[d] credit risk, potential profit and expenditure, defendants' financial status and other players involved in the case." 195 Juridica spreads investments across substantive areas, such as intellectual property, price-fixing, and shareholder disputes. Fields noted that " $90 \%$ of cases [were] settled without a lengthy trial or resolved through motions," which allowed "for a quick turnaround on profit when the right case [was] selected." 196 Commercial-claims lenders hope that the pickiness with which they conduct their due diligence and their selectivity will "send[] a powerful message to the opposing side with respect to the likely outcomes, thus encouraging settlements." 197 Consequently, they accept cases with quality lawyers who have a proven success rate.

When lenders loan plaintiffs' law firms money, however, their incentives align more with the law firm than the client. Because recourse loans are secured by all of the law firm's assets, financiers' due diligence concentrates less on the particulars of any one case and more on the firm's portfolio of cases and overall financial stability. ${ }^{198}$ Of course, law firms that heavily invest in a particular type of aggregate litigation (say, Accutane, Vioxx, or Zyprexa) would be different.

192 See Glater, supra note 191, at B1 (reporting that the managing director of a Chicago financier holds these views).

193 See id. (reporting that Juridica follows this strategy). See also Hamerman, supra note 62, at 17 (quoting Mark Wells, CEO of Calunius Capital, as saying: "Litigation could take many years and if, at the end of it, you're facing a company that hasn't got the assets to meet the claim, it's not very attractive.").

194 Lauren Tara LaCapra, Hedge Fund Hell: These Funds Sue You, The Street (Jan. 23, 2009, 10:01 AM), http://www.thestreet.com/story/10459369/1/hedge-fund-hell-thesefunds-sue-you.html?puc=_tscrss.

195 Id.; see also Burford Grp. LLC, supra note 151, at 5 ("Burford does extensive due diligence before financing a matter.").

196 LaCapra, supra note 194.

197 Inst. of Mgmt. \& Admin., Litigation Funding Services Enter United States, 2009 L. FIrm Mgmt.; see also Melissa Maleske, Hedging Bets: Third-Party Litigation Funding Gains Steam in the U.S., INSIDE Couns. (Dec. 1, 2009), http://www.insidecounsel.com/2009/ 12/01/hedging-bets (discussing the selectivity with which lenders select cases).

198 See Frankel, supra note 143 (interviewing Gary Chodes, the CEO of Oasis Legal Finance Group, Michael Blum, the CEO and co-founder of LawFinance, and Paul Myers, the president of Advocate Capital, who discuss how they select cases). 
Investing in a firm like Napoli Bern, which had substantial capital tied up in one principal case with many clients-the Ground Zero workers-would require risk assessments more akin to those conducted by Richard Fields of Juridica. As a New York Times reporter and a reporter for the Center on Public Integrity explain:

Lenders employ experienced lawyers to judge the strength of cases. They consult databases showing the results of similar lawsuits, just as appraisers value homes based on recent sales. A corporate defendant may have a history of battling personal injury claims; or juries in a specific county may have a history of siding with local employers. Then they place their bets. Counsel [Financial] will invest up to $\$ 10$ million in a law firm. ${ }^{199}$

For instance, before Oxbridge Financial Group arranged for Stillwater Capital Partners to loan money to Jared Woodfill for his lawsuits against BNSF Railway, the group "spent several months reviewing the cases" and sent "lawyers to Texas to look at documents and to question Woodfill and his partners." 200 Because law firms are liable regardless of the case's outcome, they have more incentive to negotiate lower interest rates. ${ }^{201}$ Even so, Stillwater Capital Partners charges Woodfill around sixteen percent annual interest and Counsel Financial generally charges eighteen percent, significantly less than what consumer funders charge plaintiffs. ${ }^{202}$

Consumer funders, who dispense nonrecourse loans to plaintiffs and thus risk losing money if the plaintiff loses the case, must also carefully evaluate a case's merits before funding it. ${ }^{203}$ The danger, however, is that the plaintiff-knowing that she will be required to repay a minimum amount plus a percentage of the settlement-may refuse an otherwise reasonable offer and continue to trial. In one oftcited case, a plaintiff borrowed $\$ 200,000$ in exchange for agreeing to pay $\$ 600,000$ plus "a large percentage of any future recovery," which

199 Ben Hallman \& Binyamin Appelbaum, Betting on Justice: Borrowing To Sue, CTR. FOr Pub. Integrity (Nov. 15, 2010, 2:39 AM), http://www.publicintegrity.org/2010/11/15/ 2320/betting-justice-borrowing-sue.

$200 I d$.

201 See Goldstein \& Edelman, supra note 14 (quoting a source familiar with the Ground Zero workers' suit against New York City, who observed that plaintiffs' counsel had borrowed money to finance the litigation and would have to repay the loans themselves if they lost the lawsuit).

202 Hallman \& Appelbaum, supra note 199; see also Frankel, supra note 143 (reporting that consumer funder Oasis will charge a plaintiff thirty-seven percent interest on a nonrecourse loan).

203 See Frankel, supra note 143 (interviewing corporate officers of consumer funder firms, who discuss their case selection and evaluation methods); LAwmax Legal FinANCE, http://www.fundmycase.com/en/attorney_info.php4 (last visited Sept. 5, 2012) (explaining that requirements for receiving funding include compelling liability, a defendant's ability to pay, and documented damages). 
led her to reason that proceeding to trial and losing would be a net gain unless a settlement offer exceeded $\$ 1.2$ million. ${ }^{204}$ She ultimately rejected a million-dollar settlement offer and revealed her rationale to her attorneys after trial. Her attorneys then sued the lender for fraud, unfair and deceptive trade practices, and tortious interference with their contingent-fee agreement. ${ }^{205}$

Well aware of these risks, consumer funders aim to allot plaintiffs the ideal amount of money. As Dennis Shields, the president of LawCash, explains, "We want to give them enough money but also keep it on a tight rope," since a substantial advance could lead plaintiffs to decline early (but fair) settlements and take their chances at trial. $^{206}$ Likewise, too little money could lead plaintiffs to settle early-for many of the reasons that Owen Fiss identifies in Against Settlement - which would also decrease the funder's cut. ${ }^{207}$

Because procedural rules and substantive laws dictate monetary recovery (and thus the return on a third-party funder's investment), some financiers have reason to execute strategies that will change those rules and laws in ways that promote recovery. ${ }^{208}$ After all, like plaintiffs' and defense attorneys, they are repeat players. But whether a financier attempts to change these rules depends on the funder's investment strategy. If the strategy is to diversify its portfolio across substantive areas, as Richard Fields suggests is the case for commercial lenders, then there is less incentive to invest in rule changes. ${ }^{209}$ Commercial lenders seeking a quick profit are likely to accept cases that avoid the protracted appeals that attempted rule changes may entail. In that way, they differ vastly from plaintiffs' attorneys, some of whom have invested huge amounts of capital to promote legislation and set precedent in the asbestos and tobacco litigations. ${ }^{210}$

204 See Weaver, Bennett \& Bland, P.A. v. Speedy Bucks, Inc., 162 F. Supp. 2d 448, 451 (W.D.N.C. 2001) (discussing the proposed settlement).

205 Id. at 451-54; Weaver, Bennett \& Bland, P.A. v. Speedy Bucks, Inc., No. 1:00CV249, 2007 WL 2344820 , at $* 1$ (W.D.N.C. Aug. 14, 2007) (granting in part and denying in part plaintiff's motion for attorneys' fees and costs).

206 Carter, supra note 190.

207 Owen M. Fiss, Against Settlement, 93 YALE L.J. 1073, 1076-77 (1984) (explaining the ways in which resource disparities can influence settlement for economically disadvantaged plaintiffs); see also Carter, supra note 190 (explaining that "a small cash advance might encourage plaintiffs to settle early for too little").

208 See Steinitz, supra note 155, at 1312 (observing that litigation funders may have incentives to invest in changing the rules because they frequently invest in certain types of litigation).

209 See supra notes 194-97 and accompanying text.

210 See Richard P. Ieyoub \& Theodore Eisenberg, State Attorney General Actions, the Tobacco Litigation, and the Doctrine of Parens Patriae, 74 Tul. L. Rev. 1859, 1860-62 (2000) (discussing the domino effect of multiple ongoing litigations against the tobacco industry, and how it "opened access to tobacco industry documents"). 
Finally, financiers' fiduciary obligations run not to plaintiffs, as an attorney's duties do, but to their backers or shareholders. ${ }^{211}$ Although news accounts suggest that these backers are often passive and do not know where their money goes, ${ }^{212}$ these fiduciary obligations may cause financiers to pressure plaintiffs to settle early, so that they can report higher quarterly profits. ${ }^{213}$ Publicly traded companies are particularly likely to exert such pressure.

\section{III}

\section{FINANCIERS AS INTERMEDIARIES}

Layering a financier's incentives atop an already complex principal-agent relationship can fundamentally alter litigation and settlement dynamics. An investor who bankrolls a plaintiffs' law firm on a recourse basis and accrues monthly interest may care little about speedy settlements, so long as the law firm's financial solvency is not in doubt. If the loan is nonrecourse in the same scenario, then both the funder and the lawyer have powerful incentives to settle quickly, perhaps at their clients' expense. But it is also possible to overlay the financier's incentives with the plaintiffs' incentives such that the financier, who has litigation expertise, sophistication, and substantial capital involved, will monitor the attorney and counterbalance the attorney's incentives in ways that thwart at least some of the agency problems.

Still, the overlap is not perfect: There will inevitably be some slippage at the margins, which means that while funders' oversight can stymie certain types of unethical behavior, it may exacerbate others. The financier is, after all, an intermediary with its own interests at stake and is less directly accountable to the plaintiffs than the attorneys it oversees. ${ }^{214}$ Nevertheless, financiers can play an important role in funding expensive litigation that plaintiffs' firms might not be able to afford and in offsetting attorneys' financial self-interest.

\section{A. Revisiting the Missing Monitor Problem: Unbundling Agency from Financing}

Aligning financiers' incentives with plaintiffs' incentives requires the financiers to become client-like by sharing a stake in the litigation's outcome. Just as the contingent-fee arrangement partially

211 Steinitz, supra note 155 , at 1319.

212 E.g., Goldstein \& Edelman, supra note 14.

213 Steinitz, supra note 155 , at 1319.

214 See Issacharoff \& Ortiz, supra note 8, at 1644-45 (discussing proposals for how intermediaries, which are less accountable to the principals than the agents they oversee, may improve oversight of the agents). 
assigns the attorney a portion of the plaintiff's proceeds, partially assigning the funder a percentage of the proceeds in exchange for financing the lawsuit on a nonrecourse basis makes that financier a super stakeholder. ${ }^{215}$

Allowing third parties, like commercial-claims lenders, to invest in the litigation's outcome by contracting directly with plaintiffs generates two positive effects. First, it disentangles-at least in part-the lawyer's role as investor from her role as a fiduciary and advisor. When litigating no longer threatens the law firm's solvency or ability to take on other matters, the attorney's loyalty no longer divides between self-preservation and her clients: She can afford to be a faithful representative. Second, assigning a financier a percentage of the plaintiffs' winnings converts that financier into a sizeable stakeholder and incentivizes it to monitor the attorneys and the litigation's costs. Because aggregate litigation is capital-intensive, the investor can act as an advocate for the plaintiff by keeping costs reasonable. If the attorney wants to borrow money for travel and experts at a high interest rate, the investor has the incentive to prevent that transaction and finance those expenses at a lower cost. And, unlike geographically dispersed plaintiffs who face collective-action problems, a single, experienced financier can, for instance, require attorneys to keep their travel budgets reasonable.

But the need for monitoring and the degree to which agency is disentangled from risk depends chiefly on how the third-party financier compensates the lawyer for her services. This section considers three options: (1) financiers pay the attorneys an hourly rate on the billable-hour system, (2) attorneys receive a discounted contingent fee that accounts for the lack of financial risk, or (3) financiers pay attorneys on a billable-hour rate plus some small percentage of the proceeds as a bonus.

\section{Paying Plaintiffs' Attorneys on a Billable-Hour System}

Paying attorneys a billable-hour rate cleanly severs a lawyer's role as a risk-taking investor from her role as a client advisor and fiduciary. This allows the lawyer to be more loyal to her clients and diminishes her incentive to arrange a quick settlement or to collude with the defendant to settle on suboptimal terms. Moreover, a litigation-savvy

215 For an alternative argument that plaintiffs should assign their full claim to a financier, see Schanzenbach \& Dana, supra note 166, at 8-11. For an early assessment of this idea, see Kevin M. Clermont \& John D. Currivan, Improving on the Contingent Fee, 63 Cornell L. Rev. 529, 596 (1978). This "full assignment" approach works less well when plaintiffs care about participating in the litigation, as most mass tort and employment discrimination plaintiffs do. 
financier could negotiate a better hourly rate and thereby prevent astronomical fees while ensuring that the case is adequately funded. Were a quick settlement offer generous enough to cover the financier's expenses and provide it with some return on the risk, the financier might push plaintiffs to accept the settlement, but here the billable-hour attorney's self-interest checks the financier's. ${ }^{216}$ If anything, a billable-hour attorney would prefer to prolong the litigation, advise plaintiffs to wait for a better deal, and thus counterbalance the investor.

The billable-hour system also encourages lawyers to spend time counseling their clients about the alternative options available and explaining the risks of litigating versus settling, which helps curtail the effect of contrast biases and uninformed risk preferences. ${ }^{217}$ This arrangement may likewise negate some of the pressure attorneys feel to force their clients to settle and misallocate settlement funds to pay off holdouts. ${ }^{218}$ When an attorney's payday is not inherently tied to settling the lawsuit (as it is when she works on a contingent fee), it alleviates her pressing financial concerns. So, though the attorney's ability to tender finality to the defendant is still vital for achieving a satisfactory settlement, she no longer feels the accompanying financial urgency and self-interest concerns that the current system engenders.

There are hazards involved with this billable-hour option, too. For example, there is some risk that the billable-hour attorney would encourage her clients to accept a settlement that was not in their best interests if it furthered her prospects of doing repeat business with the financier. Thus, the collusion occurs not between plaintiffs' attorneys and defense attorneys, but between plaintiffs' attorneys and funders. ${ }^{219}$

But perhaps the most worrisome aspect of this compensation scheme is whether it would still attract the best and brightest plaintiffs' attorneys. Although defense attorneys on the billable-hour

216 See Coffee, supra note 33, at 342 (describing how the attorneys' interests could counterbalance those of a third-party funder in such a circumstance).

217 See supra Part II.B.2 (discussing how contrast bias and uninformed risk preferences may interfere with plaintiffs' ability to act rationally).

218 See supra Part I.B (explaining the incentives in the current system for plaintiffs' attorneys to engage in certain questionable practices).

219 See infra Part III.D.2. Collusion might occur in different forms, such as the financier paying the attorney a referral fee for clients. This would, of course, violate Rules 1.7(a)(2) and 7.2(b) of the Model Rules of Professional Conduct. Model Rules of Prof'L Conduct R. 1.7(a)(2), 7.2(b) (2011). A conflict also exists if the lawyer's interest "would materially impair [her] ability to consider alternative courses of action that otherwise might be available to a client, to discuss all relevant aspects of the subject matter of the representation with the client, or otherwise to provide effective representation." RESTATEMENT (Third) OF THE LAW Governing LAWYERs $§ 125$ cmt. c (2011). 
system make a very nice income, one rarely sees them with their own private planes and yachts, possessions not uncommon for successful mass-tort plaintiffs' attorneys. While third-party financing would increase competition among the plaintiffs' bar and may thus foster innovation and loyalty, the question remains whether plaintiffs would still receive advocacy of the same quality and creativity and whether trading some ingenuity for greater loyalty is worth the cost.

\section{Splitting the Contingent Fee Between Financiers and Plaintiffs' Attorneys}

A second option allows attorneys and financiers to split the attorneys' standard contingent fee. Here, the lawyers would receive a reduced award since they are shouldering less financial risk, but the payoff could still be quite lucrative. This option recognizes that contingent fees and their attendant rewards encourage entrepreneurial attorneys to accept monolithic cases and thus promotes ex post law enforcement. It likewise accounts for the lingering reputational risks that attorneys must shoulder despite taking on less financial risk. ${ }^{220}$

As noted, most claimants agree to a contingent fee between thirty-three and forty percent, though some judges have reduced that fee to between twenty-five and twenty-eight percent. ${ }^{221}$ Assuming the initial agreement's range provides ample incentive to accept the case's risks, the total percentage allocated to parties other than the plaintiffs should not exceed those parameters.222 Attorneys and financiers might divide the total by splitting the percentage in some agreed upon fashion.

The trouble with this financing scheme is that if both funders and attorneys operated purely on a percentage-of-the-proceeds payment plan, their incentives would overlap with one another to a certain degree, ${ }^{223}$ but not necessarily with the plaintiffs. Like the contingentfee attorney today, both would have some motivation to achieve a higher settlement since it means a greater profit, but the attendant risks of that fee arrangement would plague plaintiffs to an even

220 See supra Part II.B.1 (discussing the reputational risks borne by plaintiffs' attorneys).

221 See supra notes 68-79 and accompanying text for a discussion of fee reductions in nonclass aggregations.

222 This total range roughly aligns with the percentages permitted in Australia and the United Kingdom. For example, one Australian company receives around thirty percent of the proceeds plus their costs and one funder in the United Kingdom receives between twenty-five and fifty percent of the litigation's proceeds. Martin, supra note 138, at 107, 113.

223 Because attorneys are the ones working directly on the case, they may want to settle sooner, whereas the financiers might want the attorneys to continue working to maximize the settlement amount (and the financiers' return on the investment). 
greater degree. ${ }^{224}$ Both financiers and attorneys may prefer to settle quickly (provided the offer exceeds the costs and fees), collude with the defendant if the deal financially benefits them, pressure plaintiffs to accept an offer through questionable means, and misallocate settlement funds if it is necessary for achieving the deal's required consensus.225 The added voice of the financier may only further encourage the attorney to engage in these questionable practices. So, while a third-party funder could ensure that litigation is not underfunded and might negotiate a reduced attorneys' fee, the savings would benefit the investor, not the plaintiffs.

\section{Paying Plaintiffs' Attorneys for Their Billable Hours Plus a Small Percentage of the Gross Proceeds}

While awarding attorneys a pure percentage of the proceeds would attract creative, entrepreneurial lawyers, the better approach is for the funder to negotiate a billable-hour rate plus a small percentage of the gross proceeds as a successful litigation bonus. ${ }^{226}$ Providing a bonus and having a sophisticated financier oversee the billable hours allays at least some of the traditional objections to having a billablehour system. For example, these objections include that billable hours encourage lawyers to duplicate their efforts and not communicate effectively with their clients, fail to provide predictable client costs, and penalize efficient and productive lawyers. ${ }^{227}$ Having a financier foot the bill actually encourages attorneys to spend time communicating with their clients. And bonuses reward efficiency and productivity while helping to counteract any tendency to unduly prolong the litigation or duplicate effort. Granted, there is still some risk that attorneys might cherry pick certain cases for continued litigation (and

224 See supra Part I.B (describing the risks of contingent fees in aggregate litigation).

225 Id.

226 Splitting the net proceeds (gross proceeds minus billable hours) as opposed to the gross proceeds would incentivize the attorney to work only the number of hours that maximizes the net proceeds, which could make her indifferent to the number of hours worked. Splitting the gross proceeds, by contrast, would incentivize the attorney to work hard to maximize the overall settlement value. Clermont \& Currivan, supra note 215, at 536-37. My thanks to Kevin Clermont for this observation. Again, the total amount of the proceeds going to entities other than the plaintiff should not exceed a standard contingent-fee rate. This should not run into prohibitions on fee splitting because the financier is paying the attorney, not splitting the attorney's fee. When a third party pays someone else's fees, best practices require informed consent and an assurance that confidential information will remain protected. See Model Rules of Prof'l Conduct R. 1.8(f), 1.6, 2.1, 5.4(c) (2011). For a discussion of these issues, see infra Part III.D.1.

227 See Am. Bar Ass'n, ABA Commission on Billable Hours Report 6 (2002) (listing objections to the system of billable hours); Clermont \& Currivan, supra note 215, at 567-69 (discussing problems with the billable hour). 
the billable hours that accompany them). Yet, the attorney's reputation among the financiers might serve as a failsafe. If the attorney hopes to gain repeat business from financiers while maintaining her reputation as a faithful agent to her clients, then she may continue to litigate only where it best serves her client's interests.

By injecting a sophisticated financier into the lawsuit and making it the largest stakeholder, this arrangement improves the status quo by addressing the two principal problems identified in Part I: the potential funding gap for less established or less solvent plaintiffs' firms, and the agency problem that arises when an attorney acts as both the lawyer and investor for numerous, disaggregated plaintiffs.

First, financiers enable plaintiffs' law firms with less capital to litigate high stakes, resource-intensive cases, which increases competition within the private bar. ${ }^{228}$ Once a market for funding aggregate litigation emerges, it is also likely to spur competition among financiers. This could, in turn, mean that they would accept a lower percentage of the proceeds for stronger cases.229 Solving this problem is thus relatively straightforward, whereas the monitoring problem and the complex incentive structure that underlies it are more complicated.

Second, to address this complexity, this proposal incentivizes financiers to monitor the attorneys, while reducing the need for monitoring in the first place. The need for oversight results from bundling financial risk with the attorney's duty of loyalty to clients; self-interest in avoiding financial strain tempts attorneys to engage in self-dealing and overbearing (if not unethical) settlement practices. Uncoupling these divergent obligations permits the financier to negotiate a competitively priced fee and to monitor the monthly costs. With the lawyer's financial wellbeing secured by the financier's nonrecourse investment in the litigation's proceeds, she can faithfully and loyally represent her clients' best interests as well as counterbalance any undue settlement pressure the financier exerts.

\section{B. Decision-Making Control}

Ethical rules in the United States currently prohibit funders from interfering with or controlling litigation. ${ }^{230}$ And most financiers pub-

228 See generally RAND CTR. FOR LAw \& Pub. Policy, supra note 27, at 19 ("Thirdparty funding has the potential to make some smaller firms contenders for large cases, which may, in turn, cause increased competition with larger firms.").

229 See Molot, supra note 18, at 107 (hypothesizing that plaintiffs would be able to take advantage of competition among funders to get the best price).

230 See Model Rules of Prof'l Conduct R. 1.2(a) (2011) (requiring a lawyer to "abide by a client's decisions concerning the objectives of representation" and to "consult with the client as to the means [for pursuing those objectives]"). 
licly disavow any authority over the case, ${ }^{231}$ though some, like Richard Fields, Juridica's CEO, admit it is "sometimes a challenge to remain hands-off." 232 Fields explains:

What we do is ask clients to keep us informed if some material event happens in the case, and we ask for quarterly reports. A lot of times we work with clients to set up budgets for the case, and sometimes we bring in people to monitor billing guidelines on the client's behalf. 233

Similarly, Burford Financial states that "it leaves litigation and settlement decisions to the client and lawyer. [The company] has no authority to influence either. Clients and their lawyers may sometimes choose to solicit Burford's views, but Burford cannot and does not impose its views." 234 The terms of Burford's financing agreement with the Ecuadorian plaintiffs and subsequent reports of Burford's involvement, however, tell a different story: ${ }^{235}$ The financing affected settlement decisions by penalizing plaintiffs if they accepted an offer of less than $\$ 1$ billion; 236 Burford introduced the litigation team to lawyers in the United States; ${ }^{237}$ and Burford also reportedly remained "active in case strategy." 238 On the receiving end, lawyers observe that they have "seen everything from funders who want to be involved in everyday management [to] funders who take a hands-off approach."239

Introducing a third party into group litigation that already entails fragmented decision making raises questions about who controls major decisions such as which attorneys to hire, whether to consent to a settlement, and which litigation strategies to pursue. ${ }^{240}$ Were a financier to take on a pure monitoring role, akin to that of an institutional

231 See, e.g., Burford Grp. LLC, supra note 151, at 5 ("Burford does not replace the party in interest or direct the litigation. Burford does not hire or fire the lawyers, direct strategy or make settlement decisions. Instead, Burford is a purely passive provider of nonrecourse financing to a corporate party.").

232 Maleske, supra note 197.

233 Id.

234 Burford Grp. LLC, supra note 151, at 14-15.

235 Parloff, supra note 15.

236 Id.

237 Id.

238 Id.; cf. Abu-Ghazaleh v. Chaul, 36 So. 3d 691, 692-94 (Fla. Dist. Ct. App. 2009) (finding that the funder, which "had to approve the filing of the lawsuit; controlled the selection of the plaintiffs' attorneys; recruited fact and expert witnesses; received, reviewed and approved counsel's bills; and had the ability to veto any settlement agreements," was so involved with the litigation that it was considered a party to the suit).

239 Raymond, supra note 138 (quoting an interview with attorney James Hosking, who has used third-party funding in international arbitrations).

240 See Sebok, supra note 18, at 111 (listing decisions, in the context of a brief discussion of the difference between intermeddling profit maintenance and champerty, that funders probably could control and others that they probably could not). 
lead plaintiff in a securities class action, it would necessitate more decisional control. ${ }^{241}$ In fact, in the United Kingdom, the funders' selfregulatory code allows them either to require that litigants request and follow counsel's settlement advice or to seek a second, but binding, opinion from another attorney. ${ }^{242}$ But this level of authority reduces what little autonomy plaintiffs have over their claim once it has been lumped together with other claims; aggregating claims already empowers lawyers at the plaintiffs' expense and makes any meaningful participation in the litigation process impractical. ${ }^{243}$ And the need for autonomy matters a great deal in claims like personal injury, product liability, and employment discrimination, where claims may be independently economically marketable, but the courts or their attorneys pool them together for efficiency and consistency. ${ }^{244}$

Allocating control to financiers likewise prompts questions about conflicts of interest: A financier has fiduciary duties to its investors, whereas attorneys have loyalty obligations to their clients. ${ }^{245}$ When financiers are not attorneys, they are not subject to the rules of professional conduct that constrain the attorney-client relationship. This creates an entirely new problem-namely, that funders could theoretically finance conflicting matters and solicit clients without any corresponding duties of good faith and loyalty. ${ }^{246}$

Fortunately, unbundling financial risk from the attorney's agency requires a less overt monitor. In fact, giving the financier too much authority would simply substitute the contingent-fee lawyer's potentially overbearing settlement demands with the financier's and leave plaintiffs no better off. But the financier must have some say in certain matters.

241 See Burch, supra note 186, at 1177-79 (arguing that lead plaintiffs should be given more control over decision making than they currently receive).

242 See Civil Justice Council, A Self Regulatory Code for Third Party FunDiNG II 1.1, at 20, If 7.2, at 24 (Dec. 2010), http://blog.internationalpractice.org/wpcontent/uploads/2011/07/A-Self-Regulatory-Code-for-Third-Party-Funding.pdf.

243 See Erichson \& Zipursky, supra note 4, at 268-69 (describing and critiquing the phenomenon of "lawyer empowerment" in the mass-tort context).

244 Autonomy matters far less when claims are less about compensating the victim and more about deterring the defendant, such as antitrust, consumer fraud, and, for smaller, well-diversified investors, securities fraud cases. If the latter category of cases avoids arbitration, they are still more likely to proceed as class actions or not at all. Class actions raise special questions about notice and consent to third-party funding that this Article does not address.

245 As Roger Parloff pointed out in his Article on Burford's financing of the Ecuadorians' litigation against Chevron, this complicated relationship has the potential to dilute "the sacrosanct attorney-client relationship." Parloff, supra note 15.

246 See Steinitz, supra note 155, at 1294 (pointing out that "finance firms are not subject to the constraints imposed by the canons of professional responsibility"). 
First, like an attorney, a financier decides whether to front the litigation costs for a partial assignment of the plaintiff's proceeds on a case-by-case or litigation-by-litigation basis. Though both the attorney and financier have incentives to vet the case, those incentives differ. A lawyer with only her reputation at stake might represent high-profile, social-change litigation, whereas a financier shouldering the financial risk would prefer cases that promised significant monetary return. Second, the financier should negotiate the hourly rate and successful litigation bonus with the plaintiffs' chosen attorney. Though the total amount should not exceed what a plaintiff typically agrees to in a contingent fee, that leaves a sophisticated financier plenty of negotiating room, particularly if it funds numerous plaintiffs.

Finally, even though financiers should not control litigation strategy or dictate the settlement terms, there are two important reasons to let them provide claimants with the equivalent of an advisory opinion as to the settlement's merit. First, if claimants are actually similarly situated and likeminded, then introducing a fresh voiceperhaps one of a very different mind about the settlement offerinjects new information into the discussion, challenges the status quo, and thereby thwarts group polarization and confirmation bias. ${ }^{247}$ Introducing cognitively diverse perspectives into group decision making can often lead to novel insights, creative solutions, and enhanced problem solving through robust debate. ${ }^{248}$ It likewise helps

247 See Michael A. Hogg \& Sarah C. Hains, Friendship and Group Identification: A New Look at the Role of Cohesiveness in Groupthink, 28 Eur. J. Soc. Psychol. 323, 324 (1998) (describing the "symptoms of groupthink" and associated "defects in the decision-making process" generated by the cohesiveness of the group); Ulrich Klocke, How To Improve Decision Making in Small Groups: Effects of Dissent and Training Interventions, 38 SMALL Group Res. 437, 438-39, 460-62 (2007) (discussing studies indicating that groups that are more receptive to external information make higher quality decisions, while reporting the author's finding that introducing dissent into group discussions actually increases preference bias).

248 See Scott E. Page, The Difference: How the Power of Diversity Creates Better Groups, Firms, Schools, And Societies 7-8 (2007) (describing how members of a diverse group perceive and interpret the world differently, use different tools to solve problems, and analyze relationships between ideas differently); L. Richard Hoffman \& Norman R.F. Maier, Quality and Acceptance of Problem Solutions by Members of Homogenous and Heterogeneous Groups, 62 J. Abnormal \& Soc. Psychol. 401, 402, 407 (1961) (reporting the experimental finding that heterogeneous groups' solutions to problems are superior to those of homogeneous groups); Eden B. King et al., Conflict and Cooperation in Diverse Workgroups, 65 J. Soc. Issues 261, 272 (2009) (surveying studies suggesting that group diversity is correlated with increased creativity, communication, and cooperation); Elizabeth Mannix \& Margaret A. Neale, What Differences Make a Difference?: The Promise and Reality of Diverse Teams in Organizations, 6 Psychol. ScI. Pub. INT. 31, 33-35, 41-43 (2005) (discussing and attempting to integrate positive and negative views of the effects of group diversity); Charlan Jeanne Nemeth, Differential Contributions of Majority and Minority Influence, 93 Psychol. Rev. 23, 23 (1986) 
claimants to avoid premature consensus and reach a more informed decision. Second, it provides transparency-at least to claimantswhich promotes accountability and inhibits collusion with attorneys. ${ }^{249}$ As critics have pointed out, one of the problems with thirdparty financiers is that they influence decision making behind the scenes - through the small print of a confidential contract, or by privately conversing with the lawyers. Giving financiers the opportunity to present their position to the claimants prompts them to go on the record and provide a reasoned opinion about the settlement's merit. The claimants can then judge for themselves whether that position is contrary to their best interests, seek competent advice from counsel, and decide whether to settle. 250

\section{The Litigation Financing Agreement}

Any time a sophisticated, repeat player like a third-party financier contracts directly with what could be a legally unsophisticated clientele, the potential for overreaching exists. Preventing contractual overreaching demands a mix of informed consent in writing ex ante and the ability to fairly resolve disputes ex post.

First, because the attorney is typically the one who will refer her inventory of clients to a financier at the litigation's outset, informed consent obligates that attorney to review the funding agreement on the client's behalf and fully disclose all of the agreement's terms. ${ }^{251}$ The attorney should: (1) disclose the extent of her relationship with the funder, ${ }^{252}$ (2) discuss the benefits of the funding arrangement

("Minority viewpoints are important . . . because they stimulate divergent attention .... [E]ven when they are wrong they contribute to the detection of novel solutions and decisions that, on balance, are qualitatively better."); Stefan Schulz-Hardt et al., Dissent as a Facilitator: Individual- and Group-Level Effects on Creativity and Performance, in THE Psychology of Conflict and Conflict Management in Organizations 149, 150-54 (Carsten K.W. De Dreu \& Michele J. Gelfand eds., 2008) (describing how conflict, in the form of exposure to dissent, facilitates creativity and performance in both individuals and groups).

249 See Issacharoff \& Ortiz, supra note 8, at 1664 (discussing the importance of increasing transparency and the difficulty of doing so in principal-agent relationships).

250 But see ABA Comm'N ON ETHics 20/20, supra note 156, at 29 (suggesting that the client might be able to delegate settlement authority to a financier).

251 Most states that have considered whether it is appropriate to refer clients to thirdparty funders have concluded that it is. E.g., N.Y.C. Bar Ass'n Comm. on Prof'l and Judicial Ethics, Formal Op. 2011-02 (2011); N.J. Supreme Court Advisory Comm. on Prof'l Ethics, Advisory Op. 691 (2001); Nev. State Bar Standing Comm. on Ethics and Prof'l Responsibility, Formal Op. 29 (2003); D.C. Bar Legal Ethics Comm., Ethics Op. 196 (1989); State Bar of Ariz. Comm. on the Rules of Prof'l Conduct, Ethics Op. 91-22 (1991).

252 " $[\mathrm{T}]$ he client is entitled to know about the risks presented by the lawyer's financial and other incentives created by the contract, and to have an opportunity to provide or decline informed consent." АВА Cомм'N оn Eтнісs 20/20, supra note 156, at 19. 
(such as the ability to loyally represent the client without the tugs of financial self-interest), (3) explain how the contractual terms could adversely affect the client's interests and the drawbacks that could result from signing it, (4) advise the client about seeking advice from other counsel, and (5) explain that other attorneys might be willing to represent the client on a traditional contingent-fee basis. ${ }^{253}$

Second, in addition to providing informed consent in writing, funding agreements should not interfere with the client's right to terminate the lawyer-client relationship at any time. ${ }^{254}$ This not only avoids a conflict with public policy and ethical limitations, ${ }^{255}$ it also gives the client some immediate recourse if she feels that the attorney is not acting in her best interest. ${ }^{256}$ Because discharging an attorney could affect her broader reputation among other clients, this provision also helps prevent wrongful conduct. ${ }^{257}$ Third, deterring overreaching and collusion entails the possibility of ex post judicial review, a subject explored in Part III.D.2.

Claimants, however, do have an obligation to provide accurate information to both their attorney and financier. Withholding material facts could induce an investor to fund a claim on a fraudulent basis. When that is the case, financiers should be permitted to cease funding the litigation. For example, Juridica recently stopped funding S\&T Oil Equipment \& Machinery Ltd. in its international arbitration against Romania when the law firm King \& Spalding withdrew from representing S\&T, citing concerns that it failed to produce a critical piece of evidence. 258 In addition to rescinding its funding, Juridica also

253 See generally Model Rules of Prof'l Conduct R. 1.0(e) \& cmt. 6 (2009) (noting that the lawyer must "[o]rdinarily ... disclos[e] . . the facts and circumstances giving rise to the situation" and the "material advantages and disadvantages of the proposed course of conduct and a discussion of ... other ... options," and that "[i]n some circumstances it may be appropriate for a lawyer to advise a client . . . to seek the advice of other counsel"); Model Rules of Prof'L Conduct R. 1.4(b) (2009) (requiring lawyers to explain matters to clients so that they can make an informed decision); RESTATEMENT (THIRD) OF THE Law Governing Lawyers $§ 20$ (2000) (same); ABA Comm'n on Ethics 20/20, supra note 156 , at 19 (same).

254 But see ABA Comm'N on ETHICs 20/20, supra note 156, at 25 (concluding that giving a financier the authority to discharge an attorney is an enforceable contractual provision absent duress or unconscionability).

255 See, e.g., Balla v. Gambro, Inc., 584 N.E. 2d 104, 109-10 (Ill. 1991); Model Rules of Prof'l Conduct R. 1.16(a)(3), 1.16(c) (2010); Mich. State Bar Standing Comm. on Prof'l Ethics, Advisory Op. RI-321 (2000); Restatement (Third) of the Law Governing LAWYERS $\S \S 31-32$ (2000).

256 See Issacharoff \& Ortiz, supra note 8, at 1646.

257 Id.

258 See Nate Raymond, New Suit Against Juridica Exposes Cracks in Litigation Funding Model, The AmLaw Daily (Mar. 15, 2011), http://amlawdaily.typepad.com/amlawdaily/ 2011/03/litdailyjuridica.html. 
demanded that $S \& T$ reimburse all litigation expenses since Juridica believed that S\&T materially misrepresented the case's prospects of success, failed to disclose material information, and withheld key facts. ${ }^{259}$

\section{Implications for Reform}

Shifting the status quo from contingent-fee arrangements to litigation funding agreements necessitates reexamining historical bans on maintenance and champerty as well as contemplating how a financier may affect the attorney-client privilege, the attorney work-product doctrine, and attorney confidentiality. This section discusses those issues briefly while citing more in-depth sources for the interested reader. It also considers how financiers might affect horizontal equity, or similar outcomes, among similarly situated plaintiffs in multidistrict litigation and discusses ways to combat free-riding from other plaintiffs' attorneys.

\section{Augmenting Legal and Ethical Rules}

Several relatively easy tweaks or extensions of existing legal doctrine would facilitate the use of third-party financiers in aggregate lawsuits. First, if financiers are to take a more active role in funding aggregate litigation, they must be able to independently evaluate the claim's merits and communicate with both the plaintiffs and the attorneys without waiving plaintiffs' attorney-client privilege or losing objections based on the work-product doctrine. ${ }^{260}$ Although some financiers rely principally on publicly filed pleadings and memoranda and thus do not need access to privileged material, ${ }^{261}$ most financiers considering whether to invest millions of dollars in funding aggregate litigation would require that information. Sharing privileged information requires plaintiffs' informed consent to satisfy attorneys' ethical duties of confidentiality, ${ }^{262}$ but it also entails considering the attorneyclient privilege and the attorney work-product doctrine. Because lawyers generally waive the work-product doctrine only when they make disclosures that substantially increase the likelihood of putting docu-

259 Letter from Timothy D. Scrantom, Dir. of Juridica Capital Mgmt. Ltd., to Valerian Simirica, S\&T Oil Equip. \& Mach. Ltd. (Nov. 10, 2009), available at http:// amlawdaily.typepad.com/03102011juridica_1109recession.pdf.

260 See Fed. R. Evid. 502; Model Rules of Prof'l Conduct R. 1.6 (2009) (discussing confidentiality in the client-lawyer relationship).

261 ABA Cомм'N On Ethics 20/20, supra note 156, at 33.

262 See Model Rules of Prof'l Conduct R. 1.6(a) (permitting a client to give informed consent to disclose confidential information). 
ments in their adversary's hands, ${ }^{263}$ it raises fewer concerns than the attorney-client privilege.

One possibility for addressing the attorney-client privilege is to extend the common-interest doctrine to include financiers who invest in the lawsuit as well as those who considered investing. ${ }^{264}$ Covering the latter category of investors encourages price competition among financiers without jeopardizing plaintiffs' confidential information. The common-interest doctrine, which allows information sharing among those with overlapping interests, evolved from situations where two clients retained the same attorney to pursue their common interest. The doctrine has long been used by insurance companies, in joint defense strategies (such as by asbestos and tobacco defendants), and by plaintiffs involved in group litigation. ${ }^{265}$ In these contexts, the doctrine extends to "two or more clients with a common interest in a litigated or nonlitigated matter" who are represented by the same or separate lawyers ${ }^{266}$ and is intended to encourage full and efficient case preparation. Although the third-party financier seems to fit neatly under this common-interest umbrella, there is one critical matter worth clarifying: The financier and the plaintiff cannot be considered

263 See, e.g., Mondis Tech. Ltd. v. LG Elecs., Inc., Nos. 2:07-CV-565-TJW-CE, 2:08-CV478-TJW, 2011 WL 1714304, at *3 (E.D. Tex. May 4, 2011) (finding that a party could share information containing work-product information with investors without waiving its protections).

264 Currently, substantial uncertainty surrounds the privilege issue. See Fed. R. Evid. 502(b) (noting that inadvertent disclosure may waive the privilege); Leader Techs., Inc. v. Facebook, Inc., 719 F. Supp. 2d 373, 376-77 (D. Del. 2010) (refusing to extend the common interest exception to include a financier); Fla. Bar Comm. on Prof'l Ethics, Op. 00-3 (2002) (requiring attorneys to advise clients as to whether attorney-client privilege or work product might be waived before providing information to third-party funders); N.J. Advisory Comm. on Prof'l Ethics, Op. 691 (2001) (requiring attorneys to ensure that clients understand the risks of external funding, including the possibility of losing the attorney-client privilege).

265 See Edna Selan Epstein, The Attorney-Client Privilege and the WorkProduct Doctrine 274-75 (5th ed. 2007) (discussing use of the common interest privilege); Christopher B. Mueller \& Laird C. Kirkpatrick, Evidence $\S \S 5.14,5.15$ (4th ed. 2009) (same); James M. Fischer, The Attorney-Client Privilege Meets the Common Interest Arrangement: Protecting Confidences While Exchanging Information for Mutual Gain, 16 Rev. Litig. 631, 632 (1997) (same).

266 See Restatement (Third) of the Law Governing Lawyers §76 (2000) (applying the common interest privilege to those with separate attorneys); see also Restatement (Third) of the LaW Governing LaWyers $§ 75$ (2000) (applying the common interest privilege to those with the same attorney); Christopher B. Mueller \& Laird C. Kirkpatrick, Evidence $\S \S 5.14,5.15$ (4th ed. 2009) (advocating use of the common interest privilege). There have been arguments that the common interest privilege only applies to legal interests in anticipated or ongoing litigation, but this potential limit should not pose a problem in the third-party financing context, since no financing relationship would exist outside of that constraint. See United States v. Duke Energy Corp., 214 F.R.D. 383, 390 (M.D.N.C. 2003) (requiring all interested parties to share a common legal interest related to ongoing or anticipated litigation). 
joint clients of the plaintiff's attorney. If that were the case, the lawyer would have a duty of loyalty to the financier, not just to her client. That would undermine the disaggregated incentive structure that promotes loyalty to plaintiffs and checks the interests of the financier.

Second, states should continue to lift the historical prohibition on champerty such that the enforceability of a financing agreement will not hinge on a particular state's laws or an ad hoc balancing approach to conflict of laws. One recent survey showed that twenty-six of fiftyone jurisdictions (including the District of Columbia) permit champerty to some degree. ${ }^{267}$ But most jurisdictions have some restrictions to prevent the financier from promoting clearly frivolous litigation, participating in "malice champerty," 268 or "intermeddling" (controlling trial strategy or settlement). ${ }^{269}$ Further, as Anthony Sebok has explored in detail, the arguments for preserving the policies against assignment and maintenance are "not currently persuasive from either a historical or jurisprudential perspective." 270 And most studies about champerty predict that lifting the ban will be beneficial by increasing access to justice and improving the likelihood that settlements will reflect a given claim's merit, as opposed to economic pressures. ${ }^{271}$

Questionable enforceability due to the inconsistent use of the above doctrines has driven commercial-dispute lenders to include

267 Sebok, supra note 18, at 98-99 n.162 (listing the jurisdictions that permit some degree of champerty as Arizona, California, Colorado, Connecticut, Florida, Hawaii, Iowa, Kansas, Maine, Maryland, Massachusetts, Michigan, Montana, New Hampshire, New Jersey, New York, North Carolina, North Dakota, Ohio, Oklahoma, Oregon, South Carolina, Tennessee, Texas, Washington, and West Virginia). Later data suggests that Missouri should not be included among these states. The new data concerning Missouri was revealed during a conversation I had with Sebok, where he identified Missouri's inclusion as an error.

268 Malice champerty is "meritorious litigation employed for an improper end." Id. at 104-05.

269 See ABA Comm'n on Ethics 20/20, supra note 156, at 12; Paul Bond, Making Champerty Work: An Invitation to State Action, 150 U. PA. L. Rev. 1297 app. at 1333-41 (2002) (providing an overview of champerty law in the fifty states).

270 Sebok, supra note 18, at 133.

271 See, e.g., Jonathan T. Molot, A Market in Litigation Risk, 76 U. CHI. L. Rev. 367, 375-78 (2000) (advocating use of third-party financing as a way to lift economic pressures on claimants); Jonathan T. Molot, A Market Approach to Litigation Accuracy (Sept. 2425, 2009), http://www.law.northwestern.edu/searlecenter/papers/molot_accuracy.pdf (arguing that financing will increase the correlation between a case's merits and its settlement value). Some commentators have argued that lifting champerty bans will encourage frivolous lawsuits because once financiers exhaust their cache of meritorious cases, they will turn to frivolous ones. See, e.g., Paul H. Rubin, Third Party Financing of Litigation, Public Policy Roundtable on Third Party Financing of Litigation 3 (Sept. 24-25, 2009), available at http://www.law.northwestern.edu/jep/symposia/JEP_CJ_2009_Rubin. pdf. This argument, however, is less forceful in aggregate litigation, where strict claims and administrative procedures post-settlement help eliminate (or reduce the cost of) weak claims. 
arbitration provisions within their funding agreements, many of which require international arbitration 272 and none of which help develop the law surrounding alternative litigation financing. ${ }^{273}$ This move toward international arbitration, particularly clauses that require arbitrating in jurisdictions like the United Kingdom, is somewhat understandable given the uncertainty of domestic champerty and maintenance laws and the United Kingdom's general acceptance of alternative financing. If funding agreements simply included forumselection clauses as an attempt to provide certainty regarding the choice of law, some courts would refuse to dismiss or transfer those cases to the specified forum if doing so would contravene that state's public policy. ${ }^{274}$

But international arbitration requirements do little for one-time individual plaintiffs. Although commercial disputes involve a sophisticated clientele who may be familiar with the ins and outs of international arbitration, requiring the average individual mass-tort or employment-discrimination victim to arbitrate her dispute internationally would be prohibitively expensive and inconvenient. She likely would be forced to forgo her grievance, regardless of its merit. Plus, if foreign countries take alternative legal and ethical approaches to conflicts of interest, they could raise questions about impropriety that undermine both the funding agreement and the arbitration's legitimacy. ${ }^{275}$ Thus, relaxing the bans on champerty and maintenance across-the-board would ensure that these financing arrangements were enforceable in all fora and eliminate the need to arbitrate.

272 See, e.g., Complaint at 12, S\&T Oil Equip. \& Mach. Ltd. v. Juridica Inv. Ltd., No. H11-542 (S.D. Tex. Feb. 14, 2011), available at http://amlawdaily.typepad.com/ 03102010juridica_complaint.pdf (alleging that Juridica "fraudulently induced plaintiffs into entering into the arbitration provision included in the Investment Agreement, which provided for arbitration in the Bailiwick of Guernsey under London Court of Arbitration (LCIA)"); Treca Financial Solutions and Claimants Funding Agreement, II 23.2, at 27 (Oct. 31, 2010), available at $\mathrm{http}: / /$ theamazonpost.com/wp-content/uploads/Mastro-declarationExs-1-10-05jul11.pdf (requiring, in a funding agreement between Buford Financial and the Ecuadorian plaintiffs in their litigation against Chevron, that "[a]ny dispute, controversy or claim arising out of or in connection with this Agreement ... shall (to the exclusion of any other forum) be referred to and finally resolved by arbitration administered by the International Centre for Dispute Resolution in accordance with its International Arbitration Rules").

273 Most arbitration is confidential and thus does not create precedent or develop the law.

274 See The Bremen v. Zapata Off-Shore Co., 407 U.S. 1, 15-17 (1972) (suggesting that forum-selection clauses that contravene an important public policy of the forum might be unenforceable).

275 Complaint, supra note 272, at 12 (alleging that Juridica "failed to disclose that at least one of [its] non-executive directors and another lawyer, Daniel Brennan, is and was at the time of the arbitration agreement's execution, a member of the LCIA board of directors"). 


\section{Tailoring Judicial and Ethical Checks}

Both the potential for overreaching in the litigation funding agreement and the potential collusion between attorneys and financiers pose critical ethical concerns. These concerns are interrelated pragmatically - an attorney who colludes with the financier is likely to encourage clients to sign unconscionable funding agreements-and widespread use of arbitration provisions makes it nearly impossible to review these issues outside of legal ethics proceedings. The problems are both practical and legal. First, with regard to the practical problems, arbitrations make it extraordinarily difficult for all but the wealthiest plaintiffs to pursue their rights against investors, as such arbitrations often occur in international venues and require plaintiffs to retain alternative counsel. ${ }^{276}$ Widespread arbitration also precludes development of the law surrounding alternative litigation financing. Second, with regard to legal problems, the Supreme Court has recently held that financiers can prevent class or group arbitration, even if they finance plaintiffs en masse. ${ }^{277}$ Freedom of contract and court deference to arbitration provisions under the Federal Arbitration Act further limit judicial solutions. ${ }^{278}$ Even though a plaintiff might claim that the funding agreement is unenforceable based on contractual defenses like fraud, duress, or unconscionability, unless she specifically challenges the arbitration provision, courts may send those questions to the arbitrator to decide. ${ }^{279}$

276 Most studies of disciplinary actions for excessive fees or attorney misconduct support this notion. See ABA Comm'n on Evaluation of Disciplinary Enforcement, Lawyer Regulation for a New Century 11 (1992), available at http://www. americanbar.org/groups/professional_responsibility/resources/report_archive/mckay_ report.html ("The disciplinary system was not designed to address complaints about the quality of lawyers' services or fee disputes."); Lester Brickman, Contingency Fee Abuses, Ethical Mandates, and the Disciplinary System: The Case Against Case-by-Case Enforcement, 53 Wash. \& LeE L. Rev. 1339, 1345 (1996) ("Contingency fee lawyers are virtually never disciplined for charging unreasonable fees . . . ."). But see Christopher R. Drahozal, Arbitration Costs and Contingent Fee Contracts, 59 VAND. L. Rev. 729, 734 (2006) (arguing that contingent fees can "provid[e] a mechanism by which arbitration can enhance, rather than restrict claimants' access to justice").

277 See AT\&T Mobility v. Concepcion, 131 S. Ct. 1740, 1750-53 (2011) (holding that where a contract does not specifically allow class arbitration, there can be no switch from bilateral to class arbitration); see also Jessie Kokrda Kamens, Will Class Actions Survive Ruling by Supreme Court in Concepcion?, BNA Class Action Litig. ReP., May 13, 2011 (analyzing the Concepcion opinion).

278 See Thomas V. Burch, Regulating Mandatory Arbitration, Utah L. Rev. (forthcoming 2012) (manuscript at 2, 5), available at http://ssrn.com/abstract=1793303.

279 See Buckeye Check Cashing, Inc. v. Cardegna, 546 U.S. 440, 444-46, 448-49 (2006) (holding that challenges to the validity of the agreement to arbitrate may be litigated in court, whereas challenges to the contract as a whole must be litigated before the arbitrator); Prima Paint Corp. v. Flood \& Conklin Mfg. Co., 388 U.S. 395, 404 (1967) ("[I]n passing upon a $\S 3$ application for a stay while the parties arbitrate, a federal court may 
Market solutions have limited potential to do what judicial remedies cannot. If financiers compete for the best cases (meritorious claims represented by attorneys with solid reputations), then the informed consumer can shop around for financing without arbitration strings attached. The trouble is, attorneys are likely the ones referring clients to financiers. And attorneys' preferred financiers may depend more on the hourly rate and on the percentage of the proceeds the financier will pay attorneys than the clients' best interests. This brings us back to the potential for collusion between the financier and attorney. Unlike clients, who are typically one-shot players, financiers and lawyers are repeat players; their relationships are more enduring. ${ }^{280}$

This potentially powerful bond between financiers and attorneys suggests that judges must play a mitigating role by policing these financing contracts. But two developments must occur before they can do so. First, judges must know that an alternative financing arrangement exists. ${ }^{281}$ Accordingly, in multidistrict litigation, there should be mandatory, in camera disclosure of financing agreements. Currently, financing agreements contain confidentiality provisions, and financiers regularly require plaintiffs to sign additional non-disclosure agreements. $^{282}$ Although these measures keep the defendant from exploiting this information to the plaintiffs' detriment, submitting the funding agreement to the judge in camera would allow the judge not only to learn of its existence and ensure that its terms are not unconscionable, ${ }^{283}$ but also to recuse herself if she has a disqualifying rela-

consider only issues relating to the making and performance of the agreement to arbitrate."); Nagrampa v. MailCoups, Inc., 469 F.3d 1257, 1277 (9th Cir. 2006) ("If . . . the district court concludes that the challenge is not to the arbitration provision itself but, rather, to the validity of the entire contract, then the issue of the contract's validity should be considered by an arbitrator in the first instance."); Toledano v. O'Connor, 501 F. Supp. $2 \mathrm{~d} 127,141$ (D.D.C. 2007) ("The district court is therefore the appropriate forum for adjudicating all of plaintiffs' challenges - to the arbitration provision, to enforcement of that provision, and to the existence of the contract containing that provision.").

280 Steinitz, supra note 155 , at 1325.

281 This is somewhat akin to Rule 7.1, which requires corporations to identify any parent corporation owning more than ten percent of a party's stock. FED. R. CIV. P. 7.1.

282 See, e.g., Complaint, supra note 272, at 9; Treca Financial Solutions and Claimants Funding Agreement, supra note 272, II 12, at 18 (requiring claimants not to disclose the terms of the agreement for seven years after its termination and to "destroy or return all Funder Information to the Funder").

283 Judges may ensure that fees adhere to ethics and professional responsibility standards even absent a fee challenge. See, e.g., Jacobs v. Mancuso, 825 F.2d 559, 564 (1st Cir. 1987); Rosquist v. Soo Line R.R., 692 F.2d 1107, 1111 (7th Cir. 1982); In re Zyprexa Prods. Liab. Litig., 424 F. Supp. 2d 488, $492-93$ (E.D.N.Y. 2006); Farmington Dowel Prod. Co. v. Forster Mfg. Co., 297 F. Supp. 924, 925-30 (D. Me. 1969); Charles Kocoras, Comment, Contingent Fees-A Judge's Perch, 47 DePaul L. Rev. 421, $422-23$ (1998). 
tionship with the financier. ${ }^{284}$ Moreover, should it become necessary, this enables the judge to report unethical behavior between attorneys and financiers to the relevant bar authorities.

Second, as Congress has done in similar areas of consumer concern, ${ }^{285}$ it should prohibit arbitration in consumer-financing agreements. ${ }^{286}$ This would ensure some transparency in the funding process through enforcement challenges, allow consumers to vindicate their contractual rights in a convenient forum (that is, not an international venue), and, by establishing precedent through the judicial system, outline the permissible bounds of litigation funding agreements. Potential judicial enforcement also deters collusive behavior between the financier and the plaintiffs' attorneys: When they know that the agreement is not shrouded in arbitration's confidentiality and may be presented before a judge (and in publicly filed documents), they will be far less likely to engage in clandestine behavior.

\section{Maintaining Horizontal Equity Among Plaintiffs}

Just as they do now, well-financed, well-established law firms are likely to eschew alternative financing. ${ }^{287}$ Being paid on an hourly basis

284 See, e.g., Parloff, supra note 15 (discussing an instance in which a special master learned that he was co-counsel with a member of the hedge fund's board).

285 See, e.g., Dodd-Frank Wall Street Reform and Consumer Protection Act, Pub. L. No. 111-203, § 1028, 124 Stat. 1376 (2010) (creating the Bureau of Consumer Financial Protection and giving that Bureau power over arbitration provisions in "consumer financial products and services" agreements); Department of Defense Appropriations Act of 2010, Pub. L. No. 111-118, § 8116, 123 Stat. 3409 (2009) (prohibiting the government from hiring employers that require their employees to arbitrate Title VII claims or sexual assault or harassment claims); Food, Conservation, and Energy Act of 2008, Pub. L. No. 110-234, $\S 210,122$ Stat. 923 (permitting parties to opt out of arbitration in livestock and poultry contracts); John Warner National Defense Authorization Act for Fiscal Year 2007, Pub. L. No. 109-364, § 987(f)(4), 120 Stat. 2083 (2006) (exempting military personnel from having to arbitrate consumer credit disputes) (codified at 10 U.S.C. § 987(f)(4)); see also Burch, supra note 278, at 26-27; Steven Greenhouse, Labor Board Backs Workers on Joint Arbitration Cases, N.Y. Times, Jan. 6, 2012, http://www.nytimes.com/2012/01/07/business/ nlrb-backs-workers-on-joint-arbitration-cases.html.

286 This may also be a task appropriate for the newly minted Bureau for Consumer Financial Protection. Though Congress has ample authority for prohibiting arbitration awards, the Bureau's authority is less certain. The Dodd-Frank Act gives the Bureau the authority to "regulate the offering of ... consumer financial products ... under the Federal consumer financial laws" and to regulate and restrict mandatory pre-dispute arbitration agreements. Dodd-Frank Wall Street Reform and Consumer Protection Act $\S 1011$. DoddFrank defines "consumer financial product" as extending credit to consumers "primarily for personal, family, or household purposes." Id. § 1002. Although funding agreements enable consumers to litigate in the hopes of receiving damages that compensate them, their families, or their households, it is unclear whether the Bureau will decide that this falls within its auspices.

287 See Frankel, supra note 143 ("Well-financed plaintiffs firms tend to stay away from litigation finance companies; as Christopher Seeger of New York's Seeger Weiss notes, 'It's 
plus a small percentage of the proceeds may not generate the same extravagant fees that a traditional contingent fee would. ${ }^{288}$ That, plus the restrictions of having to answer to an intermediary, may only fuel the potential for horizontal inequity among similarly situated plaintiffs. For example, in the Ground Zero litigation, attorneys Paul Napoli and Marc Bern tried to pass the interest costs of borrowing money onto their clients, whereas another firm also representing Ground Zero workers borrowed nothing. ${ }^{289}$ In other words, the latter plaintiffs would have received more money for similar claims. To minimize the danger of disparate fees, the system I have proposed employs current contingent-fee rates as a presumptively adequate ceiling for financiers to include in their agreements. This keeps the absolute percentage of the proceeds going to entities other than the plaintiffs similar across the board.

\section{4. $\quad$ Taxing Free Riders}

Having attorneys with different funding arrangements involved in the same multidistrict litigation exacerbates a concern about free riders when some attorneys perform common-benefit work for all plaintiffs. The concern exists regardless of whether financiers are involved, ${ }^{290}$ but the way in which judges have handled compensation in the past—by adding to and subtracting from fee awards ${ }^{291}$ — would not only interfere with funders' contractual rights, it could deter them from investing in aggregate litigation altogether.

If the established plaintiffs firms self-fund and continue to use their strong reputations to leverage favorable settlements from defendants, they are likely to be the chosen ones serving on plaintiffs' steering committees and performing common-benefit work. ${ }^{292}$ Traditionally, judges have used the common fund theory to reduce litigation fees of lawyers who may have large client inventories, but have

ridiculous how much they charge.' Firms that can afford to usually prefer to invest their own capital in experts, case screening, discovery and trial expenses.").

288 See supra Part III.A.3.

289 Goldstein \& Edelman, supra note 14.

290 See Curtis \& Resnik, supra note 65, at 444 ("The worry is about 'free riders' who obtain clients and receive, by private contract, significant percentages of the clients' recoveries for minimal work.").

291 See supra notes 68-82 and accompanying text (discussing judicial tinkering with fee awards).

292 If plaintiffs' attorneys reach a consensus about who should serve on the steering committees, the judge often defers to that consensus. See, e.g., Prakash, supra note 66, at 13-14 (discussing Judge Fallon's ratification of the plaintiffs' attorneys' choice for steering committee chairs in the Vioxx litigation). Plaintiffs' attorneys are likely to select lawyers with established reputations as opposed to newcomers. 
done little to advance the litigation-whether by choice or not. ${ }^{293}$ But this traditional system creates free riders once financiers enter the picture. Though "outsider" attorneys paid on a "billable-hour-plus" basis (that is, those using the form of third-party financing proposed in this article) would still receive less, the financiers could receive more than they bargained for due, in part, to the efforts of trailblazing attorneys. Conversely, if the billable-hour attorney performed common-benefit work, she might receive less remuneration than would counsel working on a contingent-fee arrangement. Yet, her work benefits all of the plaintiffs. So, unless the same investor had a funding relationship with each plaintiff, the other plaintiffs' attorneys-those not using alternative financing-would be enriched without cost.

Both situations suggest that something other than the status quo is appropriate, but judicial interference with the funding relationship could undermine the positive effects of unbundling agency and risk. ${ }^{294}$ Solving this problem entails reconsidering how judges compensate plaintiffs' steering committees and common-benefit counsel. As Professors Silver and Miller have argued, committee members' compensation is best addressed by taxing the total recovery from the multidistrict litigation and then subtracting that tax from each client's attorney's fee (or financier's proceeds) such that the tax is spread across all participating plaintiffs in proportion to their recovery. ${ }^{295}$ Although this means that financiers must consider the tax in drafting the litigation funding agreement and subtract it from their overall proceeds, this is a relatively straightforward fix.

\section{IV \\ Costs, Benefits, And ObJections}

This article has set forth, in broad strokes, the normative argument in favor of allowing third-party funders to serve as the missing monitor in aggregate litigation. By unbundling an attorney's duty as

293 As Professors Silver and Miller explained in the Vioxx litigation context, when judges appoint attorneys to inside positions, they "create[ ] relationships of dependency" such that attorneys on the outskirts must "rely on a coterie of litigation managers to develop their clients' cases. The disabled lawyers' clients also lose control. They are at the mercy of lawyers they never hired and can not discharge." Silver \& Miller, supra note 41, at 119.

294 Judges lack clear authority for making these changes. The ad hoc nature with which they interfere makes the funding venture even riskier for financiers.

295 Silver \& Miller, supra note 41, at 161. One of the principal objections to this approach is that attorneys may aggregate low value cases in hopes of achieving judicial appointment. The authors suggest that judges could readily identify and exclude weak cases through, for example, requiring a licensed medical doctor to certify that each plaintiff has the particular disorder in question. Id. at 163-64. 
an agent from that of a financier, we can alleviate a principal incentive to engage in unethical behavior. And, by allowing financiers to invest in aggregate litigation's outcome, we can create an intermediary monitor. But though this manages some of the principal-agent problems in nonclass aggregation, it introduces a new twist-another entity-and a unique set of incentives that could work to the plaintiffs' detriment. So, does this improve the status quo?

This final Part addresses that question by summarizing this proposal's benefits and confronting lingering concerns. Many of the primary benefits have been discussed already, such as (1) unbundling the lawyer's financial risk from her duty of loyalty; (2) enabling the financier to negotiate a competitive rate, monitor the monthly bills, state its position on settlement, and thereby stymie group polarization; (3) engendering a system of checks whereby a loyal attorney counterbalances a financier's push for settlement; (4) using billable hours to motivate attorneys to counsel clients through litigation decisions; and (5) avoiding ethically questionable practices like quick settlements. ${ }^{296}$

The following four advantages can be added to these benefits. First, like well-capitalized contingent-fee attorneys, third-party financiers may pursue nonclass aggregation that would be uneconomical as a stand-alone case but that would provide a significant return in the aggregate. This does not include small-stakes or negative-value claims, such as consumer-fraud cases, because individual plaintiffs are unlikely to come forward in numbers that make litigation viable. It would, however, include claims like those pursued by the women in Wal-Mart Stores, Inc. v. Dukes-plaintiffs whose individual claims might not make it economical to take on a corporation like Wal-Mart, but whose claims are worth litigating collectively. Without this kind of socially desirable, deterrence-based litigation, corporations could easily trample employee or consumer rights that are uneconomical to pursue alone. ${ }^{297}$

Second, outside funding increases competition among the plaintiffs' bar in that it allows smaller or less established firms to litigate cases they might not otherwise be able to afford. ${ }^{298}$ Competition could foster innovation and creativity and drive down transaction costs for plaintiffs. And because financiers want well-credentialed attorneys handling the cases they fund, their vetting process also helps screen out unqualified lawyers.

296 See supra Parts III.A.1 and III.A.3.

297 See Schanzenbach \& Dana, supra note 166, at 10-16 (noting that third-party financing could enhance deterrence for small claims).

298 Cf. supra note 287-89 and accompanying text. 
Third, financiers may improve the correlation between settlement value and the case's merits. ${ }^{299}$ When one-time, risk-averse plaintiffs follow their attorney's advice, and that advice is animated by attorney self-interest or collusion with the defendant, the settlement value may not reflect the lawsuit's merits. Permitting a financier to assume financial risks diminishes this possibility: Attorneys can genuinely advise clients about the costs and benefits of a proceeding and make realistic settlement demands. Finally, as repeat players, financiers are likely to be more efficient than one-time clients at monitoring litigation costs and keeping attorneys' fees manageable. ${ }^{300}$

These benefits do not come without costs. Absent a judge's ability to assess the financing agreement's fairness and a claimant's capacity to air allegations of collusion between the financier and attorney in a judicial—as opposed to arbitral-forum, the potential for overreaching exists. And while alternative financing may frequently alleviate the access-to-justice problem by shifting the risk of loss to the financier, it also further commodifies legal claims. Of course, contingent-fee plaintiffs' attorneys have long been monetizing claims, often regardless of their clients' stated aims, which suggests that the status quo may not change with greater use of third-party financing. ${ }^{301}$ Either way, law firms have few incentives to take cases like employment-discrimination and civil-rights claims where injunctive and declaratory relief is a nontrivial component. One recent empirical study showed that seventy-five percent of civil-rights, twenty-nine percent of labor-and-employment, thirty-seven percent of consumer, and thirty-four percent of employee-benefits class settlements included some injunctive or declaratory relief. ${ }^{302}$ While feeshifting statutes help by shifting litigation costs to the defendant, these statutes award fees to a prevailing plaintiff at the end of the lawsuit. This does nothing to alleviate concerns about the increased costs of initiating aggregate litigation, such as higher administrative expenses. ${ }^{303}$

This commodification conundrum creates two potential, interrelated problems: underenforcement of social-change and publicinterest litigation, and inaccessibility of indivisible remedies. Public-

299 See Molot, supra note 18, at 101.

300 See id. at 112-13; see also Hylton, supra note 18, at 27.

301 See Relis, supra note 169 , at $378-79$.

302 Fitzpatrick, supra note 69, at 824 tbl.3 (studying class action settlements from 2006 and 2007). Injunctive or declaratory relief included "modification of terms of employee benefit plans, modification of compensation practices, changes in business practices, capital improvements, research, and unliquidated repairs to property." Id.

303 See supra Part I.A.1 and I.A.2 (discussing the increased costs of aggregate litigation). 
interest and social-change litigation have no hard-edged definitions, but include claims like race and sex discrimination in the workplace, ${ }^{304}$ sexual harassment, ${ }^{305}$ Fair Debt Collection Practices Act $^{306}$ violations, housing desegregation or discrimination suits, ${ }^{307}$ Americans with Disabilities Act ${ }^{308}$ violations, and even toxic torts requiring environmental cleanup. ${ }^{309}$ Each of these types of claims includes a hybrid of divisible and indivisible relief. Take Title VII, for example: Were funders to invest in Title VII litigation for a percentage of the plaintiffs' recovery, they would care mainly about compensatory damages, punitive damages, and back pay-not injunctive or declaratory relief, even though Congress first enacted Title VII with those social change goals in mind. ${ }^{310}$

Still, the availability of compensatory and punitive damages might spur funders to bankroll aggregated cases that might otherwise be ignored. Financiers would invest for the profit, but since attorneys must bring all available claims on behalf of their clients and pursue their clients' wishes as part of their duty of loyalty, they would request injunctive or declaratory relief as well. And because clients retain ultimate control over settlement decisions, ${ }^{311}$ there is less danger that attorneys might trade meaningful reforms for compensation against the clients' wishes.

Another option would be for judges to allow financiers to receive a percentage of the group's recovery under the fee-shifting statutes just as they would an attorney. If indivisible relief is a major remedial component, then courts could still use the fee-shifting statute to determine a base amount and then factor in a higher multiplier based on

30442 U.S.C. $\$ 2000$ e-5(a)-(b); see, e.g., Davis v. Coca-Cola Bottling Co. Consol., 516 F.3d 955, 965 (11th Cir. 2008).

305 See, e.g., Bremiller v. Cleveland Psychiatric Inst., 195 F.R.D. 1, 25 (N.D. Ohio 2000) (noting the availability of injunctive relief for sexual harassment).

30615 U.S.C. $\S \S 1692-1692$ p (2006).

307 See, e.g., United States v. Matusoff Rental Co., 494 F. Supp. 2d 740, 746-47 (S.D. Ohio 2007) (noting the availability of injunctive relief under the Fair Housing Act).

30842 U.S.C. $\S 12101$ (2006).

309 See, e.g., 33 U.S.C. $\$ 1319$ (b) (authorizing injunctive relief for the violation of federal water pollution standards)).

310 Albemarle Paper Co. v. Moody, 422 U.S. 405, 417-18 (1975) (noting that Congress's primary objective in passing Title VII was prophylactic and intended to add backpay to the availability of injunctive relief); $c f$. The Right Honourable Lord Justice Jackson, Review of Civil Litigation Costs: Final Report 118 (2009), available at http://www. judiciary.gov.uk/NR/rdonlyres/8EB9F3F3-9C4A-4139-8A93-56F09672EB6A/0/jacksonfinal report140110.pdf ("Third party funding is not usually feasible where non-monetary relief, such as an injunction or declaration, is the main remedy sought.").

311 See supra Part III.B (discussing decision-making control). 
the litigation's "undesirability" and the results obtained. ${ }^{312}$ Alternatively, if funders loaned money directly to law firms, as Counsel Financial did in funding Napoli Bern's Ground Zero workers' claims, then courts might consider whether it is appropriate to pass interest charges on to the defendant as part of a fee-shifting regime. ${ }^{313}$ In this way, judges can fulfill the legislative intent behind fee-shifting statutes and ensure that social-change litigation and remedies that seek accountability through declaratory and injunctive relief are not casualties of third-party financing.

\section{CONCLUSION}

Alternative litigation financing, if properly engineered, could help alleviate the financial pressure on the attorney-client relationship and thereby encourage ethical behavior in pursuing and settling aggregate litigation. Presently, attorneys who specialize in large-scale litigation bear the burden of funding it-a practice that prevents lawyers with less capital from entering the field and tempts those who do fund litigation to protect their own financial interests by betraying their duties to their clients. If financial risk is no longer an integral part of an attorney's relationship with her clients, several new possibilities arise. First, financiers might bankroll talented attorneys who could not otherwise afford to initiate aggregate litigation. Second, new entrants could intensify competition among the plaintiffs' bar that could encourage innovation and drive down fees. Finally, given the increased costs and risks associated with multidistrict litigation as opposed to class actions, allowing financiers to enter the picture ensures that meritorious, large-scale suits will not wither alongside the class action. To be sure, adding an intermediary can introduce competing incentives and is thus not a cure-all for every principal-agent problem. But third-party financiers offer a promising means with which to manage some of these problems in aggregate litigation.

312 Courts typically consider some or all of the following factors when determining a lodestar amount: (1) the time and labor involved; (2) the novelty and difficulty of the questions; (3) the skill required; (4) preclusion of other employment by the attorney; (5) the customary fee; (6) whether the fee is fixed or contingent; (7) time limitations imposed by the client or by circumstance; (8) the amount involved and the results obtained; (9) the experience, reputation, and ability of the attorneys; (10) the undesirability of the case; (11) the nature and length of the lawyer-client relationship; and (12) awards in similar cases. E.g., Johnson v. Ga. Hwy. Express Inc., 488 F.2d 714, 717-19 (5th Cir. 1974).

313 Judge Hellerstein forbade attorneys from passing the litigation financing's interest costs on to their clients in the Ground Zero workers litigation. Mireya Navarro, Judge Rejects Legal Fees in 9/11 Settlement, N.Y. Times, Aug. 28, 2010, at A17. Given that he cited fairness grounds, this may not be a barrier in fee-shifting litigation, since the idea behind fee-shifting statutes is that plaintiffs would not have to incur attorneys' fees at all but for the defendant's wrongdoing. 